\title{
Aspects of Pathogen Genomics, Diversity, Epidemiology, Vector Dynamics, and Disease Management for a Newly Emerged Disease of Potato: Zebra Chip
}

\author{
Hong Lin and Neil C. Gudmestad
}

First author: United States Department of Agriculture-Agricultural Research Service Crop Diseases, Pests and Genetics Research Unit 9611 S. Riverbend Avenue, Parlier, CA 93648; and second author: Department of Plant Pathology, North Dakota State University, Fargo 581086050.

Accepted for publication 17 December 2012.

\begin{abstract}
Lin, H., and Gudmestad, N. C. 2013. Aspects of pathogen genomics, diversity, epidemiology, vector dynamics, and disease management for a newly emerged disease of potato: Zebra chip. Phytopathology 103:524-537.

An overview is provided for the aspects of history, biology, genomics, genetics, and epidemiology of zebra chip (ZC), a destructive disease of potato (Solanum tuberosum) that represents a major threat to the potato industries in the United States as well as other potato-production regions in the world. The disease is associated with a gram-negative, phloem-limited, insect-vectored, unculturable prokaryote, 'Candidatus Liberibacter solanacearum', that belongs to the Rhizobiaceae family of $\alpha$-Proteobacteria. The closest cultivated relatives of ' $\mathrm{Ca}$. L. solanacearum' are members of the group of bacteria known as the $\alpha-2$ subgroup. In spite of the fact that Koch's postulates sensu stricto have not been fulfilled, a great deal of progress has been made in understanding the ZC disease complex since discovery of the disease. Nevertheless, more research is needed to better understand vector biology, disease mechanisms, host response, and epidemiology in the context of vector-pathogen-plant interactions. Current ZC management strategies focus primarily on psyllid control. The ultimate control of ZC likely relies on host resistance. Unfortunately, all commercial potato cultivars are susceptible to ZC. Elucidation of the ' $\mathrm{Ca}$. L. solanacearum' genome sequence has provided insights into the genetic basis of virulence and physiological and metabolic capability of this organism. Finally, the most effective, sustainable management of ZC is likely to be based on integrated strategies, including removal or reduction of vectors or inocula, improvement of host resistance to the presumptive pathogen and psyllid vectors, and novel gene-based therapeutic treatment.
\end{abstract}

Additional keywords: genetic diversity, potato psyllid, psyllid Bactericera cockerelli.

Zebra chip (ZC) is a destructive disease of potato (Solanum tuberosum) that has emerged in North America as well as other potato-production regions in the world. The disease has caused significant economic losses to the U.S. potato industry. ZC was first discovered around Saltillo, Mexico in the 1990s (24,37,98). In the early 2000s, it was reported in commercial potato fields in the Pearsall and lower Rio Grande valley areas of Texas. By 2006, the disease had spread to most potato-production areas in Texas as well as other potato-production states, including Arizona, Kansas, Colorado, California, Nevada, and New Mexico (74). ZC was reported in New Zealand in 2008 (52) and, more recently, from Idaho, the Columbia Basin of Washington, and Oregon $(18,22)$.

$\mathrm{ZC}$-affected potato plants exhibit a range of foliar symptoms that resemble those of the purple top wilt symptoms caused by the

Corresponding author: H. Lin; E-mail address: hong.lin@ars.usda.gov

http://dx.doi.org/10.1094/PHYTO-09-12-0238-RVW

This article is in the public domain and not copyrightable. It may be freely reprinted with customary crediting of the source. The American Phytopathological Society, 2013. clover proliferation phytoplasma (37). Foliar symptoms include stunting, chlorosis, swollen nodes, proliferated axillary buds, aerial tubers, browning of the vascular system in stems, and leaf scorching (Fig. 1A and B). Belowground plant symptoms include enlarged lenticels of the underground stem, collapsed stolons, brown discoloration of the vascular ring, necrotic flecking on internal tuber tissues, and, occasionally, streaking of the medullary ray tissues (Fig. 1C) (37). At the time the disease was identified, the causal agent was unknown. To investigate the possible causal agents, insect transmission and graft experiments were conducted to determine whether infectious agents were transmissible to healthy plants or due to nonbiological factors such as heat stress (heat necrosis) or toxicity (psyllid toxin). In addition, research also was conducted to determine whether the symptoms were caused by nutritional deficiency, a toxin or other abiotic factor, or some combination of these factors. Although researchers were not able to consistently associate the disease with any specific causes, results from graft- and insect-transmission experiments suggested that there was likely a transmissible factor, probably a vascular plant pathogen, virus, or prokaryote or bacterial-like organism (BLO), that was associated with ZC $(24,71)$. 
These results were further supported by transmission electron microscopy studies, where BLOs were observed in the vascular tissue of infected plant parts that were similar to the phloemrestricted proteobacteria which are associated with the "basses richesses" syndrome of sugar beet (24). Because the symptoms of ZC resembled those of phytoplasma-associated diseases, studies were subsequently carried out to determine whether leafhoppers or potato-tomato psyllid Bactericera cockerelli (Šulc) was a primary vector responsible for transmission of a ZC-causing agent. Results from cage trial studies demonstrated that plants infested by potato psyllids developed ZC foliar symptoms and characteristic ZC discoloration in tubers $(71,74)$. However, at that time, the causal agent of ZC was still unknown. To identify the causal pathogen or pathogens, polymerase chain reaction (PCR) primers detecting pathogens associated with vascular-restricted diseases, including cucurbit yellow vine disease, marginal chlorosis of strawberry, Pierce's disease of grapevine, and "stolbur-like" phytoplasma, were used to screen DNAs extracted from ZCaffected and healthy potato. However, attempts to amplify specific known disease-prokaryote products from a suspect ZC-associated prokaryote failed to obtain consistent results from ZC-diseased potato or psyllids or other insect vectors (37).

A breakthrough came in April 2008, when researchers at the Plant Health and Environment Laboratory, MAF Biosecurity, New Zealand reported that a new disease of glasshouse-grown tomato (S. lycopersicum) and pepper (Capsicum annuum) plants was identified using universal prokaryote $16 \mathrm{~S}$ ribosomal DNA primer pairs that amplified a PCR product specifically from symptomatic plants $(52,54)$. This result, along with transmission electron microscopy evidence $(24,99)$, confirmed the presence of a phloem-inhabiting BLO in diseased plants, but not in healthy plants. The same New Zealand group subsequently confirmed that the same pathogen was associated with ZC of potato $(52,54)$. Sequence analysis of the amplicon indicated that it shared high similarity with the bacterial species associated with citrus huang- longbing (HLB) (also known as citrus greening). Subsequently, it was given the name 'Candidatus Liberibacter solanacearum' (55). In August 2008, a research group at the University of CaliforniaRiverside also reported a new citrus "HLB species" bacterium named ' $\mathrm{Ca}$. L. psyllaurous' responsible for tomato yellow disease caused by a bacterium transmitted by the tomato/potato psyllid (39). Because the sequences of ' $\mathrm{Ca}$. L. solanacearum' and ' $\mathrm{Ca}$. L. psyllaurous' share $>99 \%$ similarity in the $16 \mathrm{~S}$ rRNA gene, it is likely these two bacterial names are synonymous $(99,110)$. ' $\mathrm{Ca}$. L. solanacearum' is recommended as the reference to this bacterium because this name and a description of the bacterium were published in the International Journal of Systematic and Evolutionary Microbiology (55), a preferred journal for descriptions of uncharacterized bacterial species.

Since the discovery that ' $\mathrm{Ca}$. L. solanacearum' was responsible for $\mathrm{ZC}$ disease, various studies have been carried out $(1,53,56$, $76,99,110)$. All results were consistent with the conclusion that ' $C a$. L. solanacearum' is the putative causal agent of ZC of potato. Due to its fastidious nature, the ' $\mathrm{Ca}$. L. solanacearum' bacterium is, as of yet, unculturable and, thus, Koch's postulates have not been fulfilled. Consequently, conclusive detailed information regarding the general biology, physiology, and pathogenicity of ' $\mathrm{Ca}$. L. solanacearum' is lacking. In spite of these limitations, using DNA enrichment techniques and next-generation sequencing technology, the whole genome sequence of ' $\mathrm{Ca}$. L. solanacearum' has been obtained (58). Annotation of genome information provides insights into gene inventory account for biological functions, mode of pathogenicity, metabolic pathways, and nutritional requirements for this obligated intracellular pathogenic bacterium.

Evolution, speciation, and genetic diversity. The genus of 'Candidatus Liberibacter' belongs to the Rhizobiaceae family of $\alpha$-Proteobacteria. There are four plant-pathogenic species of bacteria in this genus $(8,46,55)$. Among the four pathogenic Liberibacter spp., three are associated with citrus HLB worldwide
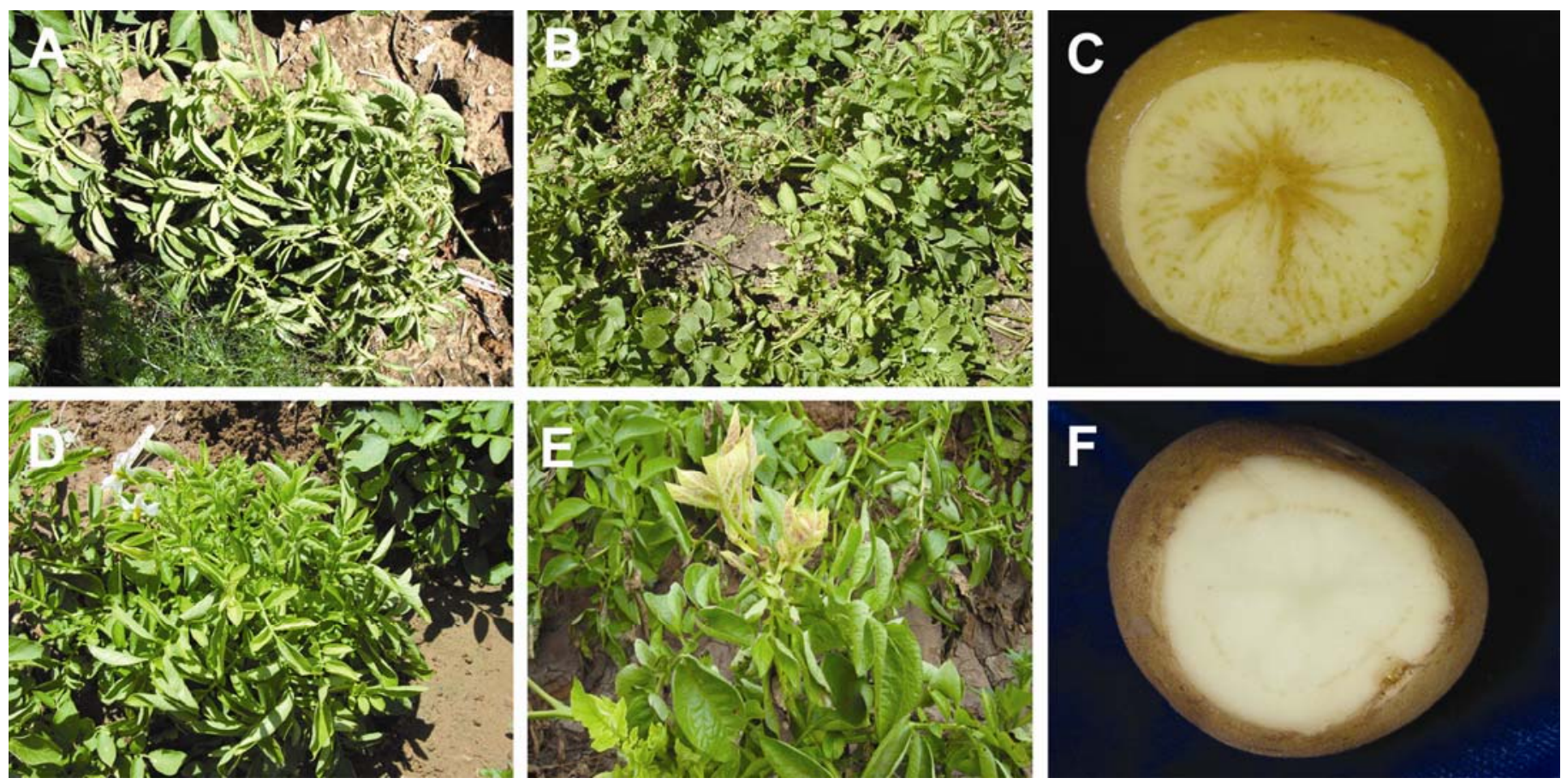

\section{FIGURE 1}

Disease symptomatology associated with $\mathbf{A}$ to $\mathbf{C}$, zebra chip $(\mathrm{ZC})$ and $\mathbf{D}$ to $\mathbf{F}$, psyllid yellows (PY) of potato. A, Early symptom development of 'Candidatus Liberibacter solanacearum' infections in potato foliage; B, advanced foliar symptoms of ZC; and C, medullary streaking and flecking in tuber flesh. D, Early symptom development of PY in potato foliage; E, advanced symptom development of PY; and $\mathbf{F}$, mild vascular discoloration of potato tubers due to PY. 
and each is named based on its presumptive origin: ' $C a$. L. asiaticus' from Asian countries, ' $\mathrm{Ca}$. L. africanus' from South Africa, and ' $\mathrm{Ca}$. L. americanus' from South America (8). HLB is a destructive disease of citrus that represents a major threat to the citrus industry worldwide. ' $\mathrm{Ca}$. L. solanacearum' is the species associated with potato $\mathrm{ZC}$ disease. Phylogenetic analyses of the 16S rRNA gene indicated that ' $\mathrm{Ca}$. Liberibacter' spp. belong to the $\alpha$-Proteobacteria group, and their closest cultivated relatives are members of the group of bacteria known as the $\alpha-2$ subgroup (46). Duan et al (27) constructed a phylogenetic analysis using 94 nonhorizontal transfer, orthologous gene sequences from $\approx 50$ species of $\alpha$-Proteobacteria. Results indicated that ' $\mathrm{Ca}$. L. asiaticus' is an early-branching member of the Rhizobiaceae family. This multi-gene-based sequence analysis is in agreement with other gene-based analyses $(8,26)$. These results also suggested that the genome of ' $\mathrm{Ca}$. L. asiaticus' had evolved rapidly (27). Such rapid genome evolution is typical of host-restricted symbionts or pathogens (67). Discovery of ' $\mathrm{Ca}$. L. solanacearum' as the putative causal agent of ZC sparked a research interest in understanding the origin and evolutionary relationships of this bacterium with other Liberibacter spp. A phylogenetic tree constructed using the neighbor-joining method clustered all three HLB-associated ' $C a$. Liberibacter' spp. along with ' $C a$. L. solanacearum' into a monophyletic group based on 16S rRNA gene sequences (56). Interestingly, both ' $\mathrm{Ca}$. L. americanus' and ' $\mathrm{Ca}$. L. solanacearum' were closely positioned proximal to the basal node followed by other two species, ' $\mathrm{Ca}$. L. asiaticus' and ' $\mathrm{Ca}$. L. africanus', indicating early divergence of ' $\mathrm{Ca}$. L. americanus' followed by ' $C a$. L. solanacearum' (56) (Fig. 2).

Shortly after the report of ' $\mathrm{Ca}$. L. solanacearum' in New Zealand, a new strain of ' $C a$. L. solanacearum' associated with carrot (Daucus carota), a nonsolanaceous crop, vectored by carrot psyllid (Trioza apicalis), was identified in Finland (72). This was followed by another report of an apparently nonpathogenic Liberibacter sp. named ' $C a$. L. europaeus' naturally vectored by pear psyllid pest Cacopsylla pyri (L.) in Italy (88). Based on these research findings, it is expected that ' $\mathrm{Ca}$. Liberibacter' spp. have undergone rapid evolutionary divergence, speciation, and adaptation to a wider range of hosts since the divergence from their ancestors. Genetic diversity of ' $\mathrm{Ca}$. L. solanacearum' is probably much larger than previously expected (56).

To determine the genetic diversity of ' $\mathrm{Ca}$. L. solanacearum' in agricultural ecosystems, haplotypes of ' $\mathrm{Ca}$. L. solanacearum' were characterized based on single nucleotide polymorphism (SNP) typing in the sequences of $16 \mathrm{~S}$ rRNA, 16S/23S ISR, and
50S rplJ-rplL ribosomal gene loci (82). Two haplotypes were identified in North and Central America, and in New Zealand, which agreed with the reports based on clade relationships of ' $\mathrm{Ca}$. L. solanacearum' isolates based on 16s rRNA gene sequence analyses (Table 1) $(99,110)$. A third haplotype was only found in a single isolate of ' $\mathrm{Ca}$. L. solanacearum' vectored by carrot psyllid in northern Europe (82). It is not clear whether this haplotype can also cause potato ZC disease. With the availability of the complete genome sequence of ' $\mathrm{Ca}$. L. solanacearum', Glynn et al. (34) developed multilocus sequence typing (MLST) markers for this bacterium. MLST marker systems have been widely used for typing and strain differentiation (34). This marker system is designed from a series of genomic housekeeping gene loci (usually 7 to 10 loci) located throughout the genome of the organism of interest (44). Housekeeping genes are selected for MLST because they undergo relatively little change in sequence over time. However, sequence variations due to insertion/deletion (INDEL) or SNPs within these loci may reflect pathogen adaptation. For example, mutation by synonymous nucleotide substitution will not alter amino acid sequences due to degeneracy of the genetic code and, therefore, such mutations will not be subject to natural selection whereas nonsynonymous mutation causing changes in amino acids will result in increased or decreased fitness. Using a panel of 10 MLST markers, two sequence types (ST-1 and ST-2) were identified, representing two major lineages in U.S. populations, whereas only one type was detected in Mexico (ST-1) and New Zealand (ST-2) isolates. Interestingly, two lineages of ' $\mathrm{Ca}$. L. solanacearum' isolates identified by this MLST marker system agreed with the analyses based on conserved genes such as rRNA and other gene loci (Table 1) $(82,99,110)$.

In addition to the markers mentioned above, another marker system, named simple sequence repeat (SSR) (also known as variable number tandem repeat or microsatellite), was developed (57). A genome-wide sequence search led to the identity of SSR loci in the ' $\mathrm{Ca}$. L. solanacearum' genome representing mono-, di-, tri-, and tetra-repeat units in perfect or imperfect repeat motifs. Due to the compact nature of bacterial genomes, some SSR loci reside in or near coding regions or in upstream regulatory regions and, therefore, have functional and structural properties. In contrast to conserved gene-based markers, this marker system possesses high discrimination power for differentiating strains within populations that have evolved over a relatively short time scale. The sequence variations in SSR loci among individual isolates can be used to assess genetic diversity within a clonal complex

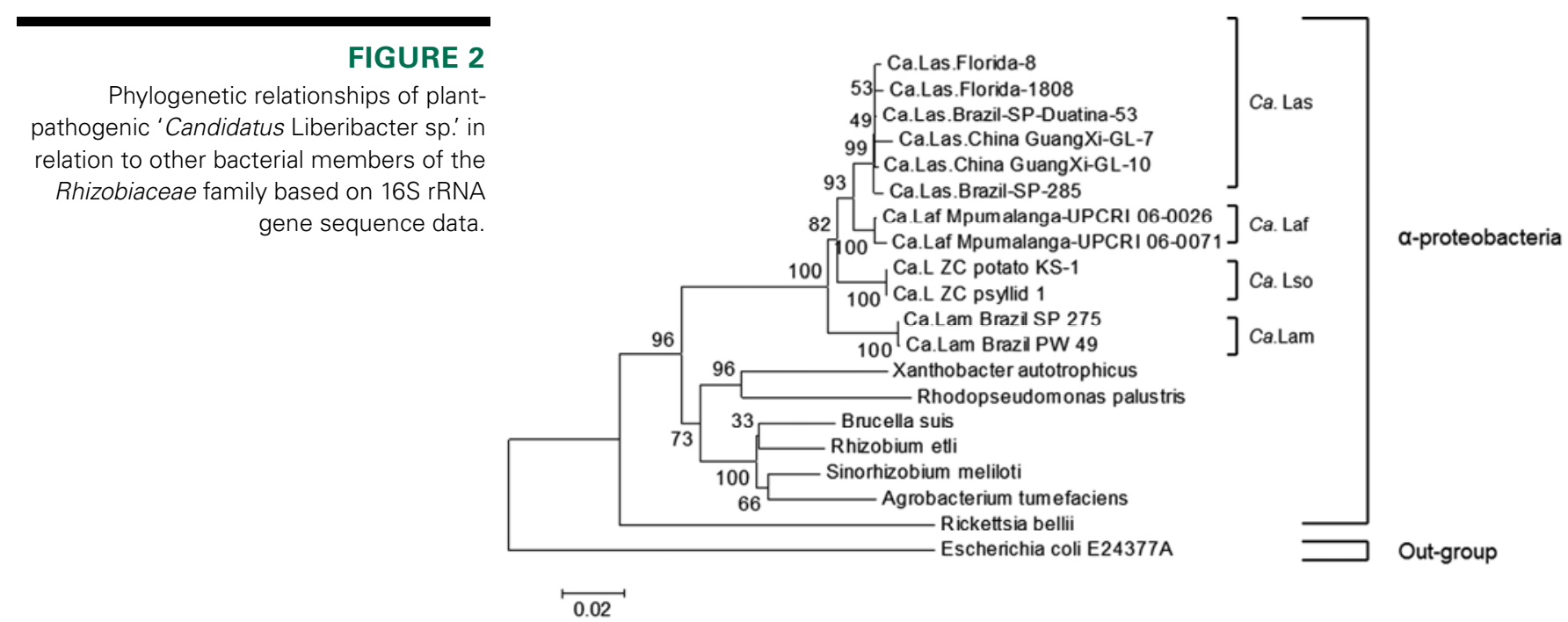


(96). Not surprisingly, two major lineages were also identified in U.S. ' $C a$. L. solanacearum' populations (Table 1). Although genetic analyses detected two lineages in agricultural population systems, the biological implication is yet to be determined. Interestingly, genetic analyses indicated that the occurrence of identical haplotypes was not restricted to any particular geographical area or host cultivar. These overlapping patterns were also observed by SNP-based typing analyses (82). In contrast to natural populations, it is expected that frequent exchange of plant materials in agricultural productions could facilitate the movement of ZC-affected materials, which could largely account for such non-pattern geographical distribution among identical haplotypes. Additionally, SSR DNA markers associated with hypervariable sequence regions can provide sufficient resolution for differentiating closely related isolates and for tracking genotypes of interest. Thus, these markers could help identify the source of invasive strains.

Pathogens with higher diversity and evolutionary potential will likely pose a higher risk of overcoming host resistance or evolving to reduce the efficacy of disease control measures (65). Understanding genetic diversity and evolutionary potential of ' $\mathrm{Ca}$. L. solanacearum' populations is critical for development of disease management strategies and tactics. Currently, information regarding the population structure and genetic diversity, as well as evolutionary and epidemiological relationships, among ' $\mathrm{Ca}$. L. solanacearum' isolates in agricultural populations is limited. Pathogen genetic analyses, in combination with advances in the understanding of the spatial and temporal dynamics of the epidemiology of the disease, will facilitate development of effective integrated pest and disease management for the ZC problem.

General features of ' $\boldsymbol{C} \boldsymbol{a}$. L. solanacearum' genome. The genome of ' $\mathrm{Ca}$. L. solanacearum' is composed of $1.26 \mathrm{Mbp}(\mathrm{Na}-$ tional Center for Biotechnology Information [NCBI] GenBank accession number CP002371) in a circular chromosome which encodes a total of 1,192 putative proteins coding sequence. In all, $\approx 68 \%$ of them are predicted to be homologous with known putative functions, and the rest of them are assigned to hypothetical proteins with unknown functions (Table 2). These numbers are similar to the ' $C a$. L. asiaticus' genome. ' $C a$. L. solanacearum' and ' $\mathrm{Ca}$. L. asiaticus' have a $\mathrm{G}+\mathrm{C}$ content of 35.24 and $36.48 \%$, respectively, which is considerably lower than the $\approx 60 \%$ $\mathrm{G}+\mathrm{C}$ content observed for most bacterial species in the Rhizobiaceae family $(16,35,111)$. Sequence analysis identified three copies of complete rRNA operons (16S, 23S, and 5S), 45 genes encoding for tRNAs, and $\approx 35$ genes identified as pseudogenes in the ' $C a$. L. solanacearum' genome (Table 2). No plasmids were found in either Liberibacter genome. Comparative analyses of the ' $C a$. L. solanacearum' and ' $C a$. L. asiaticus' genomes revealed that $\approx 884$ protein-coding sequences are common to both organisms (58). Notably, 236 coding sequences from ' $\mathrm{Ca}$. L. solanacearum' have no corresponding orthologs in ' $\mathrm{Ca}$. L. asiaticus'. On the other hand, 186 coding sequences from ' $\mathrm{Ca}$. L. asiaticus' have no corresponding orthologs in ' $\mathrm{Ca}$. L. solanacearum'. Compara-

TABLE 1

Genetic variations of 'Candidatus Liberibacter solanacearum' associated with zebra chip ${ }^{\mathrm{a}}$

\begin{tabular}{lcc}
\hline $\begin{array}{l}\text { Sequencing data } \\
\text { on rRNA }\end{array}$ & $\begin{array}{c}\text { Simple sequence } \\
\text { repeat }\end{array}$ & $\begin{array}{c}\text { Multilocus } \\
\text { sequence typing }\end{array}$ \\
\hline Clade 1 or haplotype A & Lineage 2 (type 1) & ST 2 \\
\hline Clade 2 or haplotype B & Lineage 1 (type 2) & ST 1 \\
\hline
\end{tabular}

a From Glynn et al. (34), Lin et al. (57), Nelson et al. (82), and Wen et al. (110). tive sequence analyses of ' $C a$. L. solanacearum' and ' $C a$. L. asiaticus' genomes show a high level of synteny, suggesting that both circular chromosomes are descendants of a common ancestor. Intriguingly, analyses of two Liberibacter genomes revealed that nearly $30 \%$ of open reading frames in ' $\mathrm{Ca}$. L. solanacearum' and ' $\mathrm{Ca}$. L. asiaticus' have no known function. This implies that a number of biochemical pathways remain to be identified. An incredible biological diversity among novel protein families has been observed in bacterial genomes (87).

Functional determination of these novel genes will improve our knowledge for better understanding of these disease-associated, putative pathogenic bacteria. Recent advances in sequencing technology led to the discovery of a high correlation between the number of genes and the genome size of bacteria. Most bacterial genomes range in size from $0.5 \mathrm{Mbp}$ to upward of $10 \mathrm{Mbp}$, with the average of $1 \mathrm{~kb}$ per gene. Molecular characterization of various microbial genomes has revealed that many pathogenic and mutualistic intracellular bacterial species have smaller genomes than their free-living relatives $(5,33,68)$. The loss of a great number of genes results in the reduction of genome size that is often associated with the adaptation to an obligate lifestyle, in which many molecules can be directly acquired from the host $(33,83)$. The phloem-restricted Liberibacter bacteria have small genomes, $\approx 1.2 \mathrm{Mbp}$. Likewise, the reduction of genome size through gene loss is associated with the evolutionary adaption to a lifestyle as an obligate intracellular pathogen that largely depends on intermediate metabolites acquired from its hosts.

Bacteriophages, or phages, are bacterial viruses. Two homologous segments of prophage sequences were identified in the ' $\mathrm{Ca}$. L. solanacearum' genome (P-I and P-II) (Fig. 3) (58). Sequence analysis showed that one of the prophage segments in ' $\mathrm{Ca}$. L. asiaticus' strain psy62 has a high degree of similarity with the prophage sequences of ' $\mathrm{Ca}$. L. solanacearum' genome but no circular phage sequence was identified in either Liberibacter genome $(27,58)$. More recently, two circular phage genomes (SC1 and SC2) were identified in ' $C a$. L. asiaticus'-infected periwinkle (Catharanthus roseus) and dodder plants (Cuscuta campestris) (115). In the Asian citrus psyllid, however, both were found integrated in tandem in the ' $\mathrm{Ca}$. L. asiaticus' UF506 genome as prophage. Sequence analysis showed that SC2 appears to be derived from $\mathrm{SC} 1$ but lacks lysis genes and functions as lysogenic conversion. SC1, on the other hand, seemed to be a fully functional, temperate phage with a lytic cycle that appears to be activated when the ' $\mathrm{Ca}$. L. asiaticus' host infects plants but not when inhabiting psyllids (115). It is not clear whether a lack of a circular phage genome in ' $\mathrm{Ca}$. L. solanacearum' is due to the fact that sequenced genomes were derived from ' $\mathrm{Ca}$. L. solana-

TABLE 2

General genome features of 'Candidatus Liberibacter solanacearum' and ' $C a$. L. asiaticus'

\begin{tabular}{lcc}
\hline Genome features & $\begin{array}{c}\text { 'Ca. } \mathbf{L} . \\
\text { solanacearum' }\end{array}$ & $\begin{array}{c}\text { 'Ca. } \mathbf{L} . \\
\text { asiaticus' }\end{array}$ \\
\hline Size $(\mathrm{bp})$ & $1,258,278$ & $1,227,204$ \\
\hline GC $(\%)$ & 35.2 & 36.5 \\
\hline Protein coding genes & 1,192 & 1,136 \\
\hline Hypothetical proteins & 405 & 362 \\
\hline rRNA operons & 3 & 3 \\
\hline tRNA genes & 45 & 44 \\
\hline Pseudogenes & 35 & 32 \\
\hline
\end{tabular}


cearum'-infective psyllids or to some other factor. It remains to be determined experimentally whether such lysogenic and lytic conversions are also the case in an infected host, such as when ' $C a$. L. solanacearum' infects potato plants. Alignment of the two Liberibacter genomes suggests that several recombination events have occurred since the divergence of these two species from a common ancestor (58). Phage integration events appear to play a key role in the rearrangements in the Liberibacter genomes. In addition to the two prophage genome sequences, there are a number of prophage-like elements and phage remnants distributed throughout the ' $C a$. L. solanacearum' genome, presumably derived from multiple ancestral bacteriophage integration events.

Virulence determinants. One of the most powerful approaches for the analysis of pathogen genomes involves computational bioinformatics identifying genes homologous to known virulence factor genes. Sequence-similarity-based searches such as BLAST and position-specific iterated BLAST against a reference database facilitate identification of orthologous genes with the predicted putative functions. Annotation of the ' $\mathrm{Ca}$. L. solanacearum' genome sequence provides a basis for understanding the hostpathogen interaction that leads to disease development. Many gram-negative plant-pathogenic bacteria possess a type III secretion system (T3SS) to inject effector proteins directly into host cells. T3SSs are encoded by hypersensitive response and pathogenicity genes, which cause disease in susceptible plants but elicit the hypersensitive response in resistant plants (14,59). Interestingly, no T3SS was identified in the ' $\mathrm{Ca}$. L. solanacearum' genome, nor were offensive virulence factors such as cell-walldegradation enzymes, cellulose, pectinase, xylanase found (58). Lack of a T3SS apparatus has been found in some insectmediated transmission and vascular-restricted bacteria, including 'Ca. L. asiaticus' and Xylella fastidiosa (27,102,107). Presumably, this secretion apparatus might not be necessary because the initial infection of this intracellular pathogen is mediated via direct injection into the host cell by its insect vector.
In spite of missing a classical gene-for-gene model in the ' $\mathrm{Ca}$. L. solanacearum' genome, other genes associated with putative roles in virulence or pathogenicity were identified, including genes involved in ion transport. For example, the zinc transport system is composed of a cluster of three genes $(\mathrm{ZnuABC})$ that encode a prokaryotic-type $\mathrm{ABC}$-family protein complex (30). It is predicted that the putative zinc transport system is a high-affinity cation carrier that shuttles zinc ions across the inner membrane of ' $C a$. L. solanacearum' (4). Results of a recent study of ' $C a$. L. asiaticus' suggested that the disruption of this system may present a viable target not only to mitigate HLB symptom severity by making more free zinc available to the plant but also by providing a means to decrease the overall virulence of the bacterium itself (106). ZC-affected potato plants often have yellowing symptoms resembling zinc deficiency, likely associated with the presence of this putative high-affinity zinc carrier. Therefore, the silencing of this gene or the identification of specific inhibitors of this bacterial transporter may be a way to mitigate ZC symptoms. Sequence analysis predicted that the ' $\mathrm{Ca}$. L. solanacearum' genome encoded iron-transport and accumulation (ITA) systems. The ITA system consists of a five-gene cluster found in the ' $\mathrm{Ca}$. L. solanacearum' genome and some other pathogenic microbes; however, this system is missing from the citrus HLB-associated ' $C a$. L. asiaticus' (58). It is hypothesized that this gene cluster encodes proteins involved in iron scavenging, transport, and sequestration based on their similarity to known iron transporters and gene arrangement $(28,89)$. Because $\mathrm{ZC}$-affected plants sometimes mimic plants with iron deficiency, perhaps this phenotype is related to a high-affinity iron uptake system possessed by ' $\mathrm{Ca}$. L. solanacearum'. Thus, functional confirmation of one or more of the genes in the ITA cluster will be necessary to identify the target to develop a gene-based therapy for an effective $\mathrm{ZC}$ disease treatment. Another pathogenicity gene that was identified in the ' $\mathrm{Ca}$. L. solanacearum' genome is a locus encoding an NahG-like salicylate hydroxylase. Overwhelming evidence demonstrates that

Lso P-I

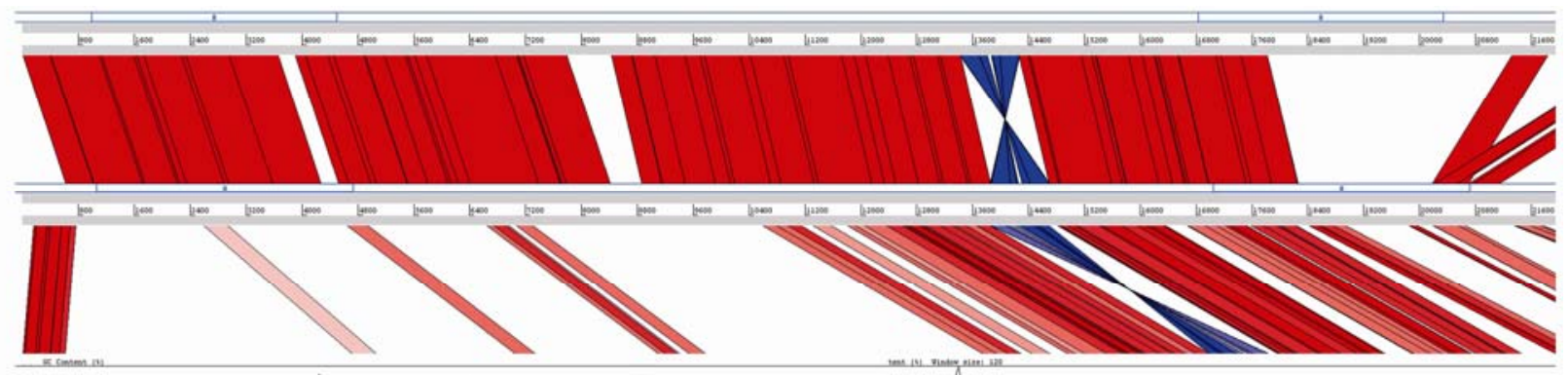

Las Prophage

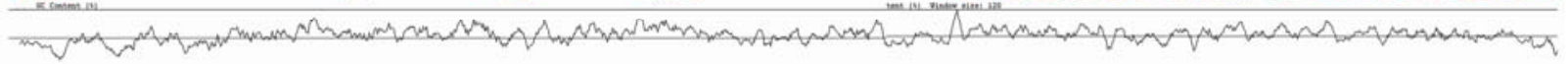

Los P-II

Las Prophage

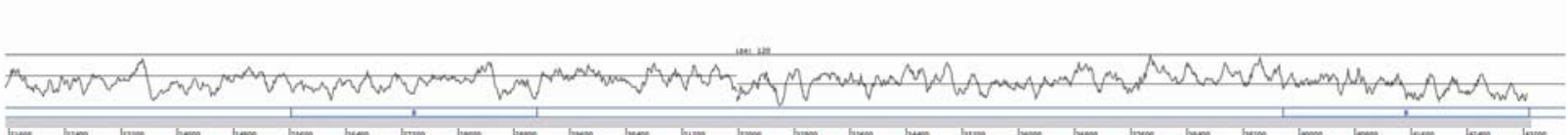

Lso P-I

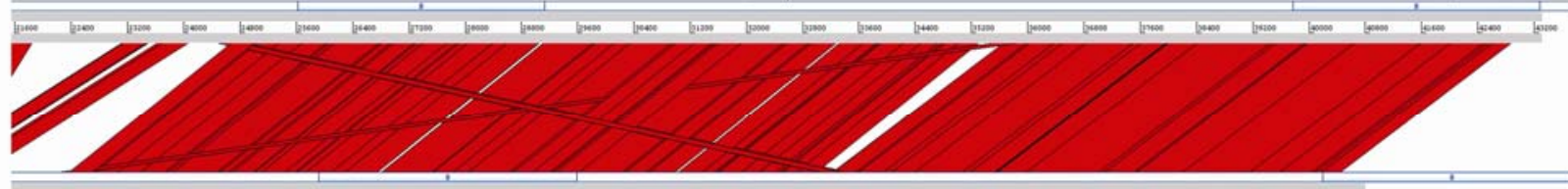

Lso P-II

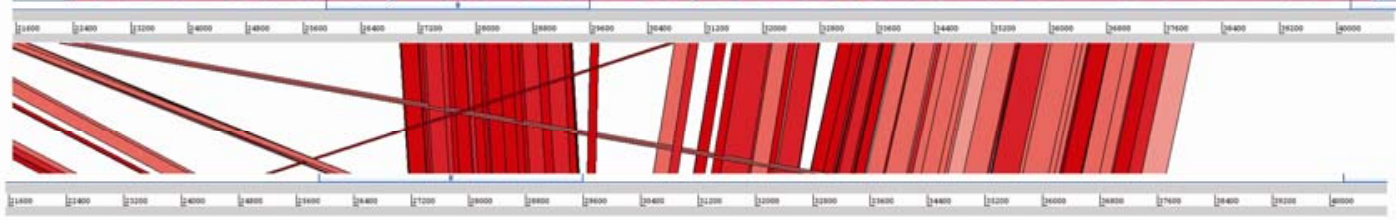

Las Prophage

\section{FIGURE 3}

Syntenic conservation between prophage sequences of 'Candidatus Liberibacter solanacearum' (P-I and P-II) and 'Candidatus Liberibacter asiaticus' (Las Prophage). Colored bands represent tBLASTx similarity: collinear (red) and inverted (blue). 
salicylic acid (SA) accumulation is essential for expression of multiple modes of plant disease resistance (9). Transgenic tobacco and Arabidopsis thaliana expressing the bacterial enzyme salicylate hydroxylase cannot accumulate SA, because it is rapidly degraded to catechol by the introduced enzymatic activity $(7,113)$. This defect not only makes the plants unable to induce systemic acquired resistance (SAR) but also leads to increased susceptibility to viral, fungal, and bacterial pathogens. Therefore, a functional defect of the salicylate hydroxylase gene in ' $\mathrm{Ca}$. L. solanacearum' may enhance host SAR in response to ' $C a$. L. solanacearum' infection. Liberibacter spp. have not been successfully cultured in vitro. Consequently, conventional gene knock-out techniques cannot be applied to determine gene function. Elucidation of the function of these virulence genes will likely provide further fundamental insights into how this pathogenic bacterium survives with its hosts and elicits disease development, as well as facilitate development of new gene-based therapeutic treatment strategies for this potato disease.

Metabolic properties. ' $\mathrm{Ca}$. L. solanacearum' is environmentally restricted to the sieve cells of phloem vessels of potato plants or in the salivary glands of potato psyllids. Thus, its lifestyle reflects adaptive features to nutritional niches in both hosts. The complete genome sequence of ' $C a$. L. solanacearum' allows reconstruction of detailed predictive metabolism models based on bioinformatics. Annotation of the ' $\mathrm{Ca}$. L. solanacearum' genome revealed that it encodes a large number of membrane-transporterrelated proteins. Membrane transports are essential for the movement of substrates across a permeable barrier of the cell membrane. Transporters enable the acquisition of organic nutrients and inorganic elements, efflux of toxin compounds, ion homeostasis, signal sensing, energy production, and various important cellular functions (84). ' $C a$. L. solanacearum' contains a nearly complete set of genes encoding enzymes in glycolytic pathways and enzymes required to convert pyruvate to acetyl-coA, an important biochemical molecule for fatty acid metabolism and entry into the tricarboxylic acid cycle (58). Apparently, these enable it to effectively utilize carbon sources available in phloem sieve cells of the host for catabolic and anabolic reactions (58). Although there are a few genes for production of enzymes found in the ' $\mathrm{Ca}$. L. solanacearum' genome involving de novo biosynthesis of amino acids, at least three complete transport systems were identified. These transport systems function as a broad-range amino acid transport capability, including the L-amino acid ABC transporter, proline glycine-betaine $\mathrm{ABC}$ transporter system, and DctA-family dicarboxylate transporter. All of these transporter systems are also present in the members of Rhizobiaceae. Because both ' $\mathrm{Ca}$. L. solanacearum' and ' $\mathrm{Ca}$. L. asiaticus' lack the key enzymes involved in the terminal stages of oxidative phosphorylation pathway, it is concluded that both ' $\mathrm{Ca}$. L. asiaticus' and ' $\mathrm{Ca}$. L. solanacearum' have limited capacity for aerobic respiration, which seems to be consistent with oxygen-limited phloem cells where they have become adapted. Additionally, genes encoding for sulfur metabolism are also absent in both genomes, suggesting that both bacteria may use other alternative energy-generating pathways under anaerobic conditions. Indeed, genome analyses identified a gene encoding ATP/ADP translocase of the NttA family in both bacteria $(27,58)$. Functional analysis confirmed that this transport protein was able to import ATP directly from the host cell's cytosol and translocate it into the bacterial cell. Thus, it can be concluded that NttA provides the ' $C a$. Liberibacter sp.' cell with energy (105). This unique feature has been found in other obligate intracellular bacteria such as the intracellular bacteria Rickettsia prowazekii, Chlamydia psittaci, and Lawsonia intracellularis $(40,97)$. Surprisingly, orthologs of the NttA transport family are absent from all other Rhizobiaceae. Given the reduced size of the ' $C a$. Liberibacter sp.' (1.2 Mb) genome, it appears that this transport was acquired through hori- zontal gene transfer early in the evolution of ' $\mathrm{Ca}$. Liberibacter' spp. Although the biochemical function of the translocase was confirmed, the biological role has yet to be determined. The capability of acquiring ATP from the host could play an important role in this obligate intracellular bacterium in planta and this feature may be exploited to facilitate a means for growing an axenic culture of this bacterium in vitro (105).

The sequencing of bacterial genomes has given insight into the genomic inventory that enables prediction of putative biochemical information about ' $C a$. L. solanacearum'. The precise substrate specificity for some significant pathways could not be determined with certainty without functional confirmation. However, this type of analysis provides a good overview of the biochemical and metabolic capability of this organism, which is particularly important for unculturable bacteria where conventional bacteriological approaches are often limited or not applicable.

Aspects of the etiology and epidemiology of ZC. The etiology and epidemiology of any plant disease is likely to be complex when it involves an insect vector, and $\mathrm{ZC}$ of potato is no different. Several important aspects of the disease will be reiterated here for clarity. The putative pathogen of $\mathrm{ZC}$ is ' $\mathrm{Ca}$. $\mathrm{L}$. solanacearum' $(21,52,53,55)$ and it is vectored by the potato psyllid, B. cockerelli Šlc. The situation is made more complicated by the implication that another bacterium, ' $\mathrm{Ca}$. L. psyllaurous', is the cause of a similar, yet distinct potato disease, psyllid yellows (PY) (Fig. 1D to F) $(39,110)$. It was suggested that ' $C a$. L. psyllaurous' is a secondary endosymbiont of the potato psyllid because it was demonstrated to be both vertically and horizontally transmitted through several life stages of the insect, raising additional questions regarding the ancestry of this bacterium (39). It is not a universally held belief, however, that PY is caused by ' $C a$. L. psyllaurous' (101); instead, it may be caused by a toxin injected by the potato psyllid $(17,29)$. It is interesting to note that the association of the potato psyllid in the development of ZC $(71,74)$ predated the identification of ' $\mathrm{Ca}$. $\mathrm{L}$. solanacearum'/'Ca. L. psyllaurous' as putative pathogens of potato $(39,52,53,55)$. Molecular characterization and phylogenetic analysis of the full-length $16 \mathrm{~S}$ rRNA from the new species of ' $\mathrm{Ca}$. Liberibacter' further confirmed the association of ZC disease of potato and the potato psyllid vector (56). The etiological cause of $\mathrm{ZC}$ was further confirmed by grafting $\mathrm{ZC}$-affected plant tissue to healthy plants, which developed typical symptoms of ZC, and the etiological agent was visualized using electron microscopy, as previously indicated $(20,99)$. Using the available PCR technology, ' $C a$. L. solanacearum' has been confirmed in ZC-affected potato and tomato plants from Texas $(1,99,110)$, California (20), and Mexico $(76,77,110)$. Using a wide array of PCR primers, ' $\mathrm{Ca}$. L. solanacearum' was found to be associated with ZC-affected plants from throughout Texas in archived ZC-affected potato samples collected in 2005 to 2007 (110). The similarity among all of these 'isolates' of ' $\mathrm{Ca}$. L. solanacearum'/' $\mathrm{Ca}$. L. psyllaurous' was $>99 \%$ (110). These studies also confirmed the presence of ' $\mathrm{Ca}$. L. solanacearum'/'Ca. L. psyllaurous' in Colorado, Kansas, and Nebraska in 2008 and in seed potato tubers produced from Wyoming in 2007 (110). Of much greater concern is the outbreak of $\mathrm{ZC}$ in the major potato-producing states of Idaho, Oregon, and Washington in $2011(18,22)$. Although economic losses in these later states were confined, it does appear that $\mathrm{ZC}$ is spreading and is likely to be present wherever the insect vector B. cockerelli is found.

The vector of ZC-associated ' $C a$. L. solanacearum', $B$. cockerelli, is known to be a spatially and temporally variable insect in the United States and New Zealand $(15,61,70)$. Research has been ongoing to determine the phenology and seasonal migration of the psyllid throughout the native range, especially where it is known to be associated with ZC. It has been clearly demonstrated that psyllid populations differ in their ability to 
transmit the ZC-associated ' $C a$. L. solanacearum' in potato (69). Although the precise explanation for this variability is not clearly understood, it may be due to genetic differences among psyllid populations, haplotypes or biotypes of the ZC-associated bacterium, or both. Previously, genetic variation of potato psyllids associated with $\mathrm{ZC}$ was determined at both the biotype level and the population level using either cytochrome oxidase I or interSSR analysis (45). The goal of this type of analysis has been to compare and contrast psyllids collected at different locations and at different times of the year and ultimately determine the movement patterns of this insect. It is epidemiologically important to determine whether there are biotypes of the potato psyllid that are more efficient vectors of ' $C a$. L. solanacearum'. This information would further our understanding of insect genotypic diversity and possibly help predict the annual severity of ZC expression. It has been known for some time that there are at least two biotypes of B. cockerelli, a western and a central U.S. biotype (61). More recently, a "northwestern" biotype of $B$. cockerelli in the United States has been identified (101) and implicated in the ZC epidemic in the Pacific Northwest $(18,22)$. The impact that these different biotypes have on the epidemiology of ZC is not yet known but studies to determine the impact that psyllid populations have on disease development are ongoing.

Initially, nothing was known about acquisition and transmission of ' $C a$. L. solanacearum' and environmental effects. The successful transmission of an insect-vectored plant pathogen is largely dependent on vector transmission efficiency, and important pieces of the host-pathogen-vector relationship have been established. For example, adult psyllids have been shown to be more efficient than nymphs in transmitting ' $\mathrm{Ca}$. L. solanacearum' (12). Acquisition success is influenced by feeding site and is highest when psyllids have access to the whole plant (64). Interestingly, inoculation access period had virtually no influence on the overall incidence of $\mathrm{ZC}$, severity of disease development, and yield loss (11); however, the rate of successful inoculation increased with higher vector numbers, and plants inoculated with multiple psyllids had higher ' $C a$. L. solanacearum' titers (64). Disease progress and tuber yield is clearly independent of psyllid density $(12,64)$. A single adult potato psyllid is capable of successfully transmitting ' $C a$. L. solanacearum' to potato in as little as $6 \mathrm{~h}$ (12). Air temperatures immediately following inoculation with Liberibacter-infective psyllids have been reported to affect ZC development (75), although more recent studies suggest that air temperatures following infection have no effect on latent period or symptom development (A. Rashed and C. Rush, personal communication). The stark difference in these results may be due to differences in the haplotype of the 'Ca. L. solanacearum' or the psyllid vector used in the respective experiments; however, that information is not currently known. Temperatures as low as $17^{\circ} \mathrm{C}$ have been reported also to slow development of ' $\mathrm{Ca}$. L. solanacearum' as do temperatures $>32^{\circ} \mathrm{C}$. Interestingly, very similar effects of temperature have been observed on the insect vector $(17,60,109)$. The optimum temperature for psyllid development is estimated to be $\approx 27^{\circ} \mathrm{C}$. Egg laying, egg hatch, and nymph development also slow at $32^{\circ} \mathrm{C}$ and cease at $35^{\circ} \mathrm{C}(60)$. Therefore, vector dynamics and pathogen development appear to be similarly reduced at temperatures of $\geq 32^{\circ} \mathrm{C}$.

The source or sources of ' $C a$. L. solanacearum' from which $B$. cockerelli acquires the bacterium is still a source of speculation. Potato psyllids have long been thought to overwinter in the Lower Rio Grande Valley on wild Lycium spp. $(36,94)$. This solanaceous host also has been found to be infected with ' $C a$. L. solanacearum', albeit at very low frequencies (110). Therefore, it is suspected but not empirically proven that the potato psyllid can acquire the ZC bacterium while overwintering, which may explain why frequencies of ' $\mathrm{Ca}$. L. solanacearum' are traditionally higher early in the growing season than later (19). Titers of ' $C a$.
L. solanacearum' in potato psyllids have been demonstrated to be substantially reduced in starved potato psyllids (95), which may explain why migrating populations of $B$. cockerelli have lower ' $C a$. L. solanacearum' frequencies than those coming off overwintering hosts. Additionally, ' $C a$. L. solanacearum' is known to have a negative effect on the population growth rate of the potato psyllid by reducing fecundity and survival of nymphs (80). It is apparent that more detailed information on pathogen-vector relationships and interactions is necessary if risk assessment models are to be effective in predicting $\mathrm{ZC}$ development.

Because the potato psyllid migrates from overwintering sites, it makes epidemiological sense that the development of $\mathrm{ZC}$ is more intense along the edges of an affected field rather than further infield (112). Disease progress was best explained by a seconddegree polynomial (quadratic) equation. Perhaps more interesting was the determination that $\mathrm{ZC}$ infections in potato fields did not develop spatially in a completely random pattern but, rather, in clusters, with ZC-infected plants situated in close proximity to each other (41). However, analysis of the infection clustering did not support secondary spread of the pathogen from an initial infection point. This is in direct contrast to earlier observations of ZC development in the field in Texas, where the disease developed in "holes" or pockets (Fig. 4). It is not known whether these holes are the result of secondary spread of the pathogen from individual focal points (71) or whether these clusters of infection have formed from plant-to-plant movement of competent vectors. A very fortunate attribute of ZC development is that seedborne ' $C a$. L. solanacearum' does not appear to be epidemiologically important (42). Although the vegetative propagule used as "seed" to plant potato can harbor ' $\mathrm{Ca}$. L. solanacearum' $(42,86)$, it has not yet been demonstrated to be a source of inoculum in development of an epidemic. Seedborne ZC does have a detrimental effect on seed quality, however, largely through the reduction of germination rates and subsequent seedling vigor $(42,86)$.

Host responses. ZC causes significant losses in tuber yield $(11,42)$. The development of ZC symptoms in tubers occurs $\approx 3$ weeks after infection, after which tuber development ceases (10). Concomitantly, tuber solids began to decrease as soon as ZC symptoms began to appear. The rapid development of ZC tuber symptoms in the aforementioned studies supports previous studies on movement of ' $\mathrm{Ca}$. L. solanacearum' in potato and tomato (49). In these studies, the ' $\mathrm{Ca}$. L. solanacearum' bacterium moved in the phloem and was more readily detected in the upper- and middle-tier leaves, before it was detected in fully developed leaves, 2 to 3 weeks after initial exposure to ' $\mathrm{Ca}$. L. solanacearum'-inoculative psyllids (49). It was concluded that ' $C a$. L. solanacearum' translocation within potato and tomato plants is similar to what has been previously described for phloem-limited viruses and phytoplasmas.

A number of studies have investigated the physiological response of the host to infection at the cellular and molecular level. For example, there is evidence of cell death in potato tubers affected by ZC (66) and a build-up of host phenolics and plant defense-related proteins $(3,81,108)$. Total protein content increases threefold, which includes increases in gene expression regulatory factors such as cyclophilin and tuber storage proteins such as patatin (3). Tyrosine has been suggested to be the primary cause of enzymatic browning in potato tubers (81). Glucose and sucrose levels also are elevated in ZC-diseased tubers, reducing process quality in potato chips due to the Maillard reaction that occurs during high-temperature frying $(12,31)$. The characteristic development of this potato chip defect was the ultimate source of the name given to this potato disease, "zebra chip" (Fig. 5). Initial investigations have indicated that potato plants are more susceptible to the pathogen phenologically early in the plant's life cycle 
than later (31), although temperatures at the time of infection may affect the infection process, development of disease symptoms, and the bacterium-vector relationship (75). More recent studies indicate that plant age at the time of infection, over a broad range of temperatures, has no effect on the development of initial ZC symptoms or on the rate of symptom severity (64) (C. Rush, personal communication). These conflicting reports may be due to the specific interaction of ' $\mathrm{Ca}$. L. solanacearum' haplotypes and potato cultivar and the conditions with which the studies were performed.

Although all of the impacts proteobacterial pathogens have on affected plants are not understood, it is likely that the presence of the ZC-associated ' $\mathrm{Ca}$. L. solanacearum' in the phloem is similar to another proteobacterium, a ' $C a$. Phlomobacter sp.', and its effect on the roots of sugar beet (100). We know that ' $C a$. L. solanacearum' infection of potato phloem disrupts carbohydrate flow to belowground portions of the plant, causing a number of the symptoms associated with ZC $(11,31)$. The lack of carbohydrate flow to the roots will likely cause them to starve and decline in function, thereby causing the aboveground portions of the plant to also slowly decline and eventually die (Fig. 1A and B).

Host range. From the initial suggestion of ' $\mathrm{Ca}$. L. solanacearum' as the putative pathogenic cause of $\mathrm{ZC}$, it has been known that ' $C a$. L. solanacearum' is also associated with a number of other solanaceous hosts in addition to potato and tomato $(52,53,55)$. In New Zealand, ' $C a$. L. solanacearum' has been associated with a new disease of Capsicum sp. and tomato while also causing a potato disease very similar to $\mathrm{ZC}$ in the United States $(54,55)$. In addition, ' $C a$. L. solanacearum' also has been found to infect $S$. betaceum (tamarillo) and Physallis peruviana (Cape gooseberry) in New Zealand (53,54). ' $\mathrm{Ca}$. L. solanacearum' has been associated with a psyllid-associated disorder of carrots in several countries in Europe $(2,72,73,78,79)$. These are the first reports of a nonsolanaceous host for ' $\mathrm{Ca}$. L. solanacearum'. The association of ' $\mathrm{Ca}$. L. solanacearum' in carrot and with two other psyllid species raises interesting questions about the diversity of ' $\mathrm{Ca}$. L. solanacearum' and its specific relationship with insect vectors, which is discussed elsewhere in this review.

In the United States, a survey of ' $C a$. L. solanacearum' in solanaceous hosts in Texas found that silverleaf nightshade $(S$. elaeagnifolium Cav.), wolfberry (Lycium barbarum L.), black nightshade (S. ptychanthum Dun.), and jalapeno pepper (Capsicum annuum L.) were hosts for the $\mathrm{ZC}$-associated bacterium (110). The ' $C a$. Liberibacter' spp. detected in all of these solanaceous plant hosts had similarity indices of $99.8 \%$ to the partial 16S rRNA gene sequences compared with the sequences of the

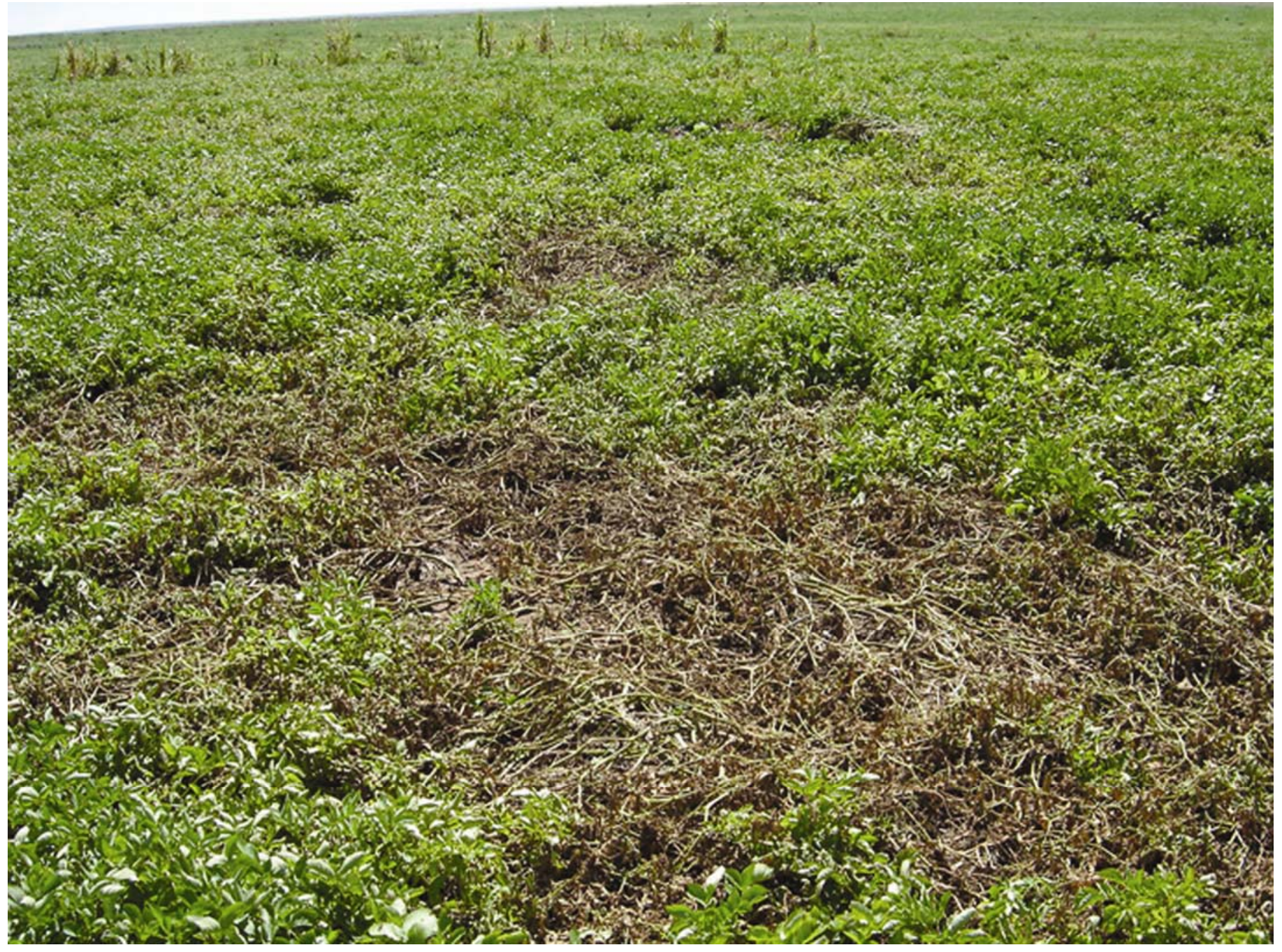

FIGURE 4

Development of zebra chip $(\mathrm{ZC})$ in a cluster of infections in the field, which initially suggested secondary spread of the ZC pathogen from an initial focal point. 
same bacterium detected in $\mathrm{ZC}$-affected potato plants (110). The role that these alternate hosts such as perennial solanaceous plants wolfberry and silverleaf nightshade have on the epidemiology of ' $C a$. L. solanacearum' is not known but further studies are warranted and should be performed, as they have been for HLB caused by ' $\mathrm{Ca}$. L. asiaticus' $(23,25)$. For any of these plant hosts to be identified as epidemiologically significant reservoirs of ' $\mathrm{Ca}$. L. solanacearum' inoculum, they will have to be demonstrated to retain the $\mathrm{ZC}$-associated ' $\mathrm{Ca}$. L. solanacearum' in an infectious state over an extended period of time and also be an important colonization host for $B$. cockerelli.

Molecular diagnosis. Detection of ' $\mathrm{Ca}$. L. solanacearum' in its insect vector is essential for studying its etiology and epidemiology and in developing effective disease management strategies (36). Because ZC is associated with a prokaryotic bacterium, most of the PCR methods developed for ' $\mathrm{Ca}$. L. solanacearum' detection have utilized a conventional PCR format, with primers to amplify $16 \mathrm{~S}$ and $23 \mathrm{~S}$ ribosomal DNA sequences $(39,50,52$, $54,91,99,110)$. Although a number of forward primers have been empirically designed based on the $16 \mathrm{~S}$ rRNA sequence of ' $\mathrm{Ca}$. L. solanacearum' (NCBI GenBank accession number EU980389 $(50,55,110)$, the reverse primer most commonly used for the PCR reaction is the Liberibacter-universal primer OI2c (47). As a result, it is not surprising that some of the primers developed to detect ' $\mathrm{Ca}$. L. solanacearum' also amplify some strains of ' $\mathrm{Ca}$. L. asiaticus' and ' $C a$. L. africanus' $(92,110)$. Fortunately, all of the
PCR primers developed to date are specific for ' $\mathrm{Ca}$. Liberibacter' spp. associated with the ZC complex and do not detect other prokaryotic plant pathogens that affect potato (110). In addition to PCR primers using $16 \mathrm{~s}$ and $23 \mathrm{~s}$ rDNA genes, more recent primers have utilized genomic DNA such as a conserved bacterial housekeeping gene, adenylate kinase (91). These primers have been demonstrated to a detection limit of $\approx 0.65 \mathrm{ng}$ (91). Genomic-based PCR primers also have been developed to facilitate detection of ' $\mathrm{Ca}$. L. solanacearum' in the potato psyllid and have been found to be valuable in determining the frequency of the bacterium in its vector (19).

Few studies have investigated the effectiveness of detecting 'Ca. L. solanacearum' in infected potato plant parts. In one study, the overall efficiency of the current PCR technology associated with the detection of true positives was demonstrated to be as low as $60 \%$ (110). Detection efficiencies have been generally determined to be higher for belowground portions of plants, such as stolons, roots, and tubers, as opposed to leaves, leaf petioles, and aboveground stems $(50,110)$. However, these results might be contradicted by more recent studies which found ' $C a$. L. solanacearum' detection frequencies higher in upper- and middletier leaves than in lower aboveground tissues; however, no attempt was made to assay belowground tissues (49). The presence of PCR inhibitors in tuber tissues can be problematic and caution needs to be exercised when using tuber tissue to detect ' $\mathrm{C} a$. L. solanacearum' infections (110).

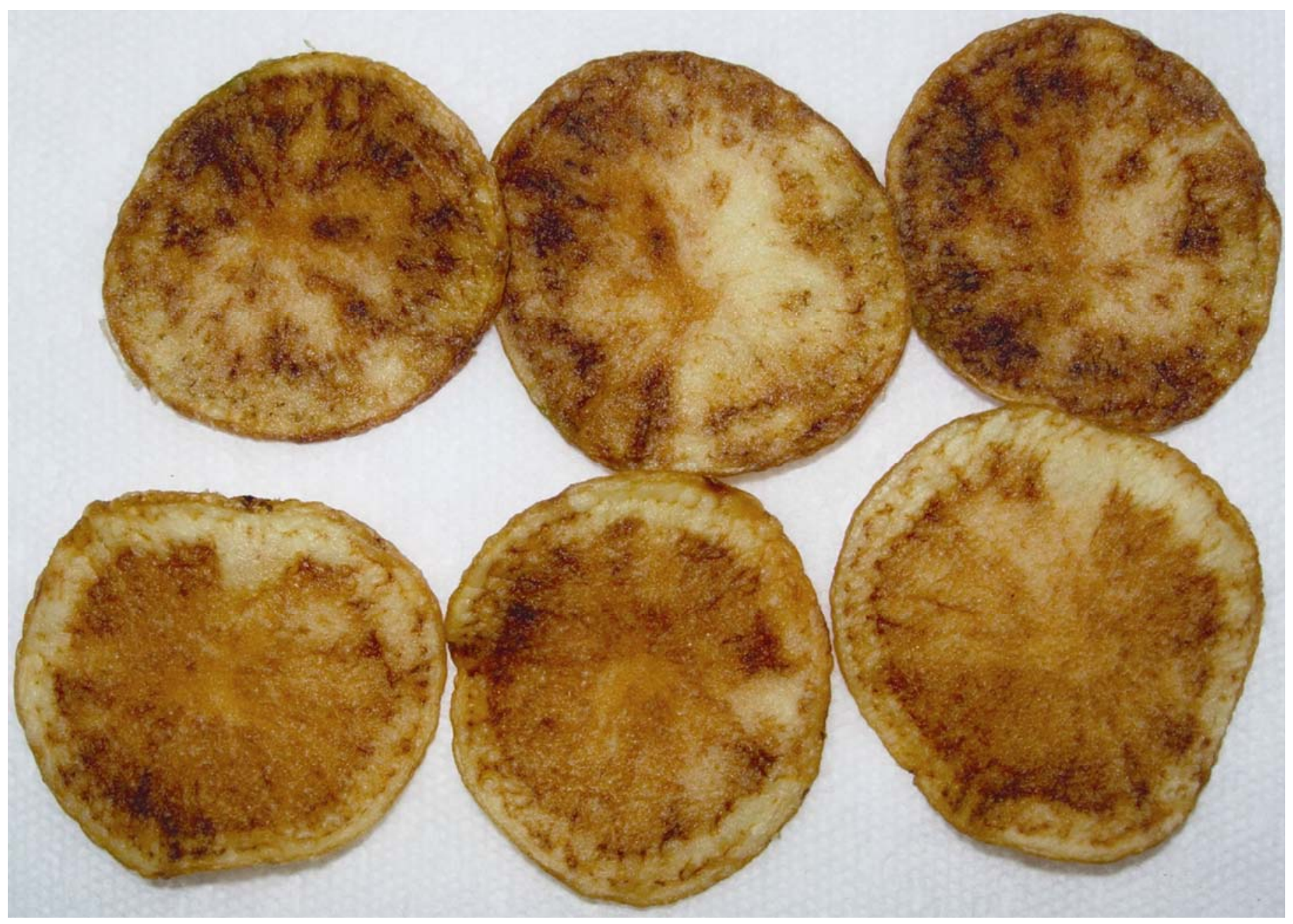

\section{FIGURE 5}

Range of symptoms of the zebra chip defect in potato chips. The development of these symptoms is due to a build-up of glucose in medullary ray tissue that caramelizes during high-temperature frying due to the Maillard Reaction. 
There has been interest in quantifying the development of ' $\mathrm{Ca}$. L. solanacearum' in hosts once the plant becomes infected. In order to accomplish this, the expected amplicon for the PCR reaction was cloned in a plasmid and the number of copies of DNA estimated using the number of base pairs in the sequence and the average molecular mass of a base pair in double-stranded DNA (50). This method was useful in determining that 20 copies of the target $16 \mathrm{~S}$ rDNA of ' $\mathrm{Ca}$. L. solanacearum' could be detected in the DNA extract of a ZC-affected plant using a quantitative (q)PCR format. Using this methodology and applying it to naturally infected potato plants from the field, it was determined that the majority of plants harbored an ' $\mathrm{Ca}$. L. solanacearum' population of $10^{5}$ to $10^{6} \mathrm{cells} / \mathrm{g}$ of tissue (50). As expected for a phloem-restricted pathogen, ' $\mathrm{Ca}$. L. solanacearum' populations were three times higher in belowground than aboveground tissue, which likely explains why detection efficiencies are much higher when belowground plant tissue is used $(50,110)$. In this study, $92 \%$ of all field samples tested positive for ' $\mathrm{Ca}$. L. solanacearum' using qPCR whereas only 40 to $46 \%$ tested positive using conventional PCR, depending on the primers used (50).

Molecular methods of pathogen detection can only be efficient when using high-quality DNA. Thus, it is extremely important to verify that the DNA is of sufficient quality to be amplified in a PCR reaction. When PCR assays utilize only a single set of primers to detect a microbe, a negative result does not distinguish between the absence of the target DNA sequences, the presence of PCR inhibitors, or poor DNA quality. As a result, a multiplex PCR platform that combines pathogen-specific primers with an internal control that utilizes a plant-based DNA sequence target could be beneficial. Two such multiplex PCR methods have been developed to detect ' $\mathrm{Ca}$. L. solanacearum' in plants, one utilizing a potato $\beta$-tubulin gene sequence $(110)$ in a conventional PCR format, the other using a plant mitochondrial cytochrome oxidase gene sequence in a qPCR format (50). The use of such an internal control determined that $19 \%$ of the DNA samples tested gave a negative ' $\mathrm{Ca}$. L. solanacearum' result due to poor DNA quality, clearly demonstrating the usefulness of such an approach (110).

Despite recent improvements in PCR detection technology $(19,91)$, there is still a need for improvement. For example, the development of a multiplex PCR format that would distinguish ' $C a$. L. solanacearum' haplotypes (57) while simultaneously determining potato psyllid biotypes $(45,103)$ could be very useful in epidemiological studies. Further improvements in qPCR also could facilitate epidemiological studies of $\mathrm{ZC}$, as demonstrated with HLB-associated Liberibacter spp. in citrus $(43,51,104)$. For example, qPCR has been found to be extremely useful in determining infestation rates of ' $\mathrm{Ca}$. L. asiaticus' in the Asian citrus psyllid in Florida (51), which were 10 to $100 \%$. PCR is currently being used to detect ' $\mathrm{Ca}$. L. solanacearum' in potato psyllids collected throughout the United States as part of a $\mathrm{ZC}$ disease management plan $(19,21)$. In contrast to the HLB situation, only $\approx 2 \%$ of these potato psyllids have tested positive for ' $\mathrm{Ca}$. L. solanacearum' (21).

Disease management. In the absence of obvious genetic resistance, it is predictable that an agricultural industry will seek the use of insecticides in an attempt to effectively manage an insect-vectored disease. ZC is a relatively new disease in the United States $(21,37)$ and, in the absence of other effective disease management strategies and tactics, efficacious insecticides have become the primary means by which the vector and, therefore, the disease are managed $(32,36,62,63)$. Most of these studies have concentrated on the efficacy of various insecticides on the life stages of the potato psyllid. For example, thiamethoxam and abamectin were found to be effective in significantly reducing adult populations of $B$. cockerelli, although residual effects on adult mortality where relatively short $(\approx 24 \mathrm{~h})$ (32).
Insecticides such as spiromesifen were found effective against nymphs (36). Unfortunately, there is a lack of evidence that the use of insecticides to manage psyllid populations will have any effect on reducing the incidence and severity of ZC disease development under conditions where potato psyllid populations harbor high frequencies of ' $\mathrm{Ca}$. L. solanacearum' infection. For that reason, a few studies involving tomato and the potato psyllid have investigated the potential to improve host resistance and insecticides to effectively manage both the vector and the disease $(62,63)$.

Current pest management practices rely on the use of insecticides to increase psyllid mortality but they can also be used to effectively manage potato psyllid populations by impacting each life stage in ways that do not affect mortality. For example, some insecticides such as imidacloprid, abamectin, and pymetrozine have been shown to reduce probing durations while concomitantly increasing the amount of time adult psyllids spend off the leaf surface, suggesting that these insecticides also act as repellents (13). Perhaps more importantly, two of the insecticides used to manage psyllid populations, imidacloprid and abamectin, also significantly lowered the transmission of ' $\mathrm{Ca}$. L. solanacearum', which may help reduce further infections (13). However, the development of insecticide resistance compromises the ability of any chemical treatment to effectively limit the rate of disease development, and some populations of potato psyllid have already been documented with resistance to imidacloprid (64).

Growers also use a variety of other management tactics to limit the economic impact of $\mathrm{ZC}$ as it affects their potato crop. Laboratory testing of psyllids obtained from a trapping network has confirmed the suspicions of growers that the highest frequencies of ' $\mathrm{Ca}$. L. solanacearum' in migrating populations occur early in the growing season (19). This may be because the potato psyllid can acquire the ZC-associated ' $\mathrm{Ca}$. L. solanacearum' from an overwintering host, such as Lycium spp. or other solanaceous hosts, that are capable of harboring the bacterium (110). It has also recently been demonstrated that the potato psyllid can overwinter on $S$. dulcamara L. in Idaho (A. Jensen, personal communication). The role that this Solanum sp. may have on the epidemiology of ' $C a$. L. solanacearum' is also warranted. As previously stated, it has also been demonstrated that colonies of B. cockerelli lose infectivity when starved (95), which may occur when psyllids migrate, thereby reducing the risk of bacteriliferous psyllids initiating a serious epidemic. As a direct result, potato growers in a number of potato-production areas of Texas where $\mathrm{ZC}$ is endemic have resorted to delaying planting so as to avoid psyllid populations less likely to be vectoring ' $\mathrm{Ca}$. L. solanacearum' (N. C. Gudmestad, unpublished data). Because psyllids move into fields from the periphery (112), potato growers also treat the edges of fields with insecticides so as to reduce the opportunity of the insect vector to become established in the entire field.

Other disease management tactics being investigated include the development of traps that attract male and female adult psyllids through the use of volatile chemical attractants (38). Entomopathogenic fungi may also provide additional components useful in an integrated pest management strategy (48) in addition to the use of kaolin particle films and other biorational insecticides which appear to be useful in repelling all developmental stages of the potato psyllid $(85,114)$. These potential alternative methods of ZC management are a priority and are being intensively investigated.

The future for disease management likely lies with diseaseresistant potato cultivars (13). Although all potato cultivars currently grown in the United States are susceptible to ZC, a number of potato genotypes have been identified in which there was a significant reduction in ' $\mathrm{Ca}$. L. solanacearum' transmission compared with susceptible controls. However, the exact nature of 
the host-parasite interaction contributing to the reduced transmission is still unclear (13). The development of ZC-resistant germplasm is a priority and is ongoing.

Conclusion and future perspectives. Since the first identification of ZC as a new disease of potato in the United States and New Zealand, a significant effort to determine the cause and, ultimately, the management of the disease has taken place. In addition to determining the cause of $\mathrm{ZC}$, we now have a much deeper understanding of the putative proteobacterium involved. Although ' $\mathrm{Ca}$. L. solanacearum' remains a relatively primitive pathogen in a genomic sense, it possesses a number of unique attributes that potentially allow it to be a successful plant pathogen. Although ' $\mathrm{Ca}$. L. solanacearum' lacks substantial enzymatic capability and a T3SS (58), its genome does have other orthologous virulence-related means at its disposal. These need to be explored further because some hosts infected with ' $\mathrm{C}$. L. solanacearum' become severely diseased, such as potato and tomato, while others such as eggplant and pepper can harbor dense populations of ' $\mathrm{Ca}$. L. solanacearum'-infected psyllids with little or no ill effect (N. C. Gudmestad, unpublished). Furthermore, studies have shown that phosphonate fungicides induce SAR in potato (6), which has been demonstrated to significantly reduce ' $C a$. L. solanacearum' titers when plants are treated prior to infection (93). It is not known whether this is related to the functional suppression or defect in the salicylate hydrolase gene in ' $C a$. L. solanacearum'. Nevertheless, there are genomic data available that may provide the basis for the development of disease management tactics in the future.

The 'Ca. L. solanacearum' vector, B. cockerelli, adds an additional level of complexity to the $\mathrm{ZC}$ disease of potato. Although it has been long recognized as an insect pest of potato in certain regions $(17,29,94,109)$, its recent association with a putative bacterial pathogen is as perplexing as it is agriculturally problematic. If ' $\mathrm{Ca}$. L. psyllaurous' is truly a secondary endosymbiont of $B$. cockerelli (39), then the question remains whether or not there are avirulent wild-type ancestors that still exist, perhaps in some other solanaceous plant host. Recent studies suggest there may be ' $C a$. L. solanacearum' haplotype-B. cockerelli haplotype interrelationships that could affect $\mathrm{ZC}$ disease development. For example, PCR testing of the western B. cockerelli haplotype revealed only infections of haplotype A ' $\mathrm{Ca}$. L. solanacearum' whereas central U.S. haplotypes of the potato psyllid are predominately infected with haplotype B ' $\mathrm{Ca}$. L. solanacearum' (A. Wen and N. C. Gudmestad, unpublished). Although we have substantial information on acquisition, transmission and effect of psyllid densities on ZC development $(11,12)$, there are no data to suggest that this is true for all haplotypes of the vector and the ZC-associated ' $\mathrm{Ca}$. L. solanacearum'.

Although there has been a great deal of progress made in our understanding of the $\mathrm{ZC}$ disease complex, it is apparent that there is much more to be learned before this disease can be managed long term in a sustainable manner. There are still substantial gaps in our knowledge of disease epidemiology, particularly as it affects vector survival and overwintering, as well as pathogen dynamics. There are also substantial gaps in our understanding of disease resistance mechanisms, which ultimately will be the primary means by which this disease is effectively and sustainably managed. Despite that, the depth of our understanding, relative to the genetic diversity of the putative pathogen and its vector, the migration of the vector, and the frequency of ' $\mathrm{Ca}$. L. solanacearum' infection, coupled with effective insect and disease management integrated pest management strategies in the short term, have been impressive for a recently developed potato disease. The expectation is that future studies will continue to improve our understanding of this pathogen-host-vector interaction, while concomitantly reducing the economic impact of $\mathrm{ZC}$ in the United States and elsewhere.

\section{ACKNOWLEDGMENTS}

Trade names or commercial products in this publication are mentioned solely for the purpose of providing specific information and does not imply recommendation or endorsement by the United States Department of Agriculture (USDA). USDA is an equal opportunity provider and employer.This work was supported by a grant from the United States Department of Agriculture NIFA-SCRI (Project number 2009-5118120176). We thank E. Civerolo for critical reading of this review article.

\section{LITERATURE CITED}

1. Abad, J. A., Bandla, M., French-Monar, R. D., Liefting, L. W., and Clover, G. R. G. 2009. First report of the detection of 'Candidatus Liberibacter' species in zebra chip disease-infected potato plants in the United States. Plant Dis. 93:108.

2. Alfaro-Fernández, A., Cebrian, M. C., Villaescusa, F. J., Hermoso de Mendoza, A., Ferrandiz, J. C., Sanjuan, S., and Font, M. I. 2012. First report of 'Candidatus Liberibacter solanacearum' in carrot in mainland Spain. Plant Dis. 96:582.

3. Alvarado, V. Y., Odokonyero, D., Duncan, O., Mirkov, T. E., and Scholthof, H. B. 2012. Molecular and physiological properties associated with zebra complex disease in potatoes and its relation with 'Candidatus Liberibacter' contents in psyllid vectors. PLoS ONE 7:e37345.

4. Ammendola, S., Pasquali, P., Pistoia, C., Petrucci, P., Petrarca, P., Rotilio, G., and Battistoni, A. 2007. High-affinity $\mathrm{Zn}^{2+}$ uptake system $\mathrm{ZnuABC}$ is required for bacterial zinc homeostasis in intracellular environments and contributes to the virulence of Salmonella enterica. Infect. Immun. 75:5867-5876.

5. Andersson, S. G. E., and Kurland, C. G. 1998. Reductive evolution of resident genomes. Trends Microbiol. 6:263-268.

6. Andreu, A. B., Guevara, M. G., Wolski, E. A., Daleo, G. R., and Caldiz, D. O. 2006. Enhancement of natural disease resistance in potatoes by chemicals. Pest. Manage. Sci. 62:162-170.

7. Bartscha, M., Gobbatoa, E., Bednareka, P., Debeyb, S., Schultzeb, J. L., Bautora, J., and Parkera, J. E. 2006. Salicylic acid-independent enhanced disease susceptibility1 signaling in Arabidopsis immunity and cell death is regulated by the Monooxygenase FMO1 and the nudix hydrolase NUDT7. Plant Cell 18:1038-1051.

8. Bové, J. M. 2006. Huanglongbing: A destructive, newly emerging, century-old disease of citrus. J. Plant Pathol. 88:7-37.

9. Brodersen, P., Malinovsky, F. G., Hématy, K., Newman, M. A., and Mundy, J. 2005. The role of salicylic acid in the induction of cell death in Arabidopsis acd11. Plant Physiol. 138:1037-1045.

10. Buchman, J. L., Fisher, T. W., Sengoda, V. G., and Munyaneza, J. E. 2012. Zebra chip progression: from inoculation of potato plants with Liberibacter to development of disease symptoms in tubers. Am. J. Potato Res. 89:159-168.

11. Buchman, J. L., Heilman, B. E., and Munyaneza, J. E. 2011. Effects of Liberibacter-infective Bactericera cockerelli (Hemiptera: Triozidae) density on zebra chip potato disease incidence, potato yield, and tuber processing quality. J. Econ. Entomol. 104:1783-1792.

12. Buchman, J. L., Sengoda, V. G., and Munyaneza, J. E. 2011. Vector transmission efficiency of Liberibacter by Bactericera cockerelli (Hemiptera: Triozidae) in zebra chip potato disease: Effects of psyllid life stage and inoculation period. J. Econ. Entomol. 104:1486-1495.

13. Butler, C. D., Gonzalez, B., Keremane, M. L., Lee, R. F., Novy, R. G., Miller, J. C., and Trumble, J. T. 2011. Behavioral responses of adult potato psyllid, Bactericera cockerelli (Hemiptera: Triozidae), to potato germplasm and transmission of 'Candidatus Liberibacter psyllaurous'. Crop Prot. 30:1233-1238.

14. Büttner, D., and He, S. Y. 2009. Type III protein secretion in plant pathogenic bacteria. Plant Physiol. 150:1656-1664.

15. Cameron, P. J., Surrey, M. R., Wigley, P. J., Anderson, J. A. D., Hartnett, D. E., and Wallace, A. R. 2009. Seasonality of Bactericera cockerelli in potatoes (Solanum tuberosum) in South Auckland, New Zealand. N. Z. J. Crop Hortic. Sci. 37:295-301.

16. Capela, D., Barloy-Hubler, F., Gouzy, J., Bothe, G., Ampe, F., Batut, J., Boistard, P., Becker, A., Boutry, M., Cadieu, E., Dréano, S., Gloux, S., Godrie, T., Goffeau, A., Kahn, D., Kiss, E., Lelaure, V., Masuy, D., Pohl, T., Portetelle, D., Pühler, A., Purnelle, B., Ramsperger, U., Renard, C., Thébault, P., Vandenbol, M., Weidner, S., and Galibert, F. 2001. Analysis of the chromosome sequence of the legume symbiont Sinorhizobium meliloti strain 1021. Proc. Natl. Acad. Sci. USA 98:9877-9882.

17. Cranshaw, W. S. 2001. Diseases caused by an insect toxin. Pages 73-74 in: Compendium of Potato Diseases. W. R. Stevenson, R. Loria, G. D. Franc, and D. P. Weingartner, eds. American Phytopathological Society, St. Paul, MN. 
18. Crosslin, J. M., Hamm, P. B., Eggers, J. E., Rondon, S. I., Sengoda, V. G., and Munyaneza, J. E. 2012. First report of zebra chip disease and 'Candidatus Liberibacter solanacearum' on potatoes in Oregon and Washington State. Plant Dis. 96:452-453.

19. Crosslin, J. M., Lin, H., and Munyaneza, J. E. 2011. Detection of 'Candidatus Liberibacter solanacearum' in the potato psyllid, Bactericera cockerelli (Šulc), by conventional and real-time PCR. Southwest. Entomol. 36:125-135.

20. Crosslin, J. M., and Munyaneza, J. E. 2009. Evidence that the zebra chip disease and the putative causal agent can be maintained in potatoes by grafting and in vitro. Am. J. Potato Res. 86:183-187.

21. Crosslin, J. M., Munyaneza, J. E., Brown, J. K., and Liefting, L. W. 2010. Potato zebra chip disease: a phytopathological tale. Plant Health Progress. Online publication. doi:10.1094/PHP-2010-0317-01-RV

22. Crosslin, J. M., Olsen, N., and Nolte, P. 2012. First report of zebra chip disease and 'Candidatus Liberibacter solanacearum' on potatoes in Idaho. Plant Dis. 96:453.

23. Damsteegt, V. D., Postnikova, E. N., Stone, A. L., Kuhlmann, M., Wilson, C., Sechler, A., Schaad, N. W., Brlansky, R. H., and Schneider, W. L. 2010. Murrya paniculata and related species as potential hosts and inoculums reservoirs of 'Candidatus Liberibacter asiaticus', causal agent of Huanglongbing. Plant Dis. 94:528-533.

24. De Boer, S. H., Secor, G., Li, X., Gourley, J., Ross, P., and Rivera. V. 2007. Preliminary characterization of the etiologic agent causing zebra chip symptoms in potato. In: New and Old Pathogens of Potato in Changing Climate. Proc. EAPR Pathol. Sect. Hattula, Finland. A. Hannukkala and M. Segerstedt, eds. Agrifood Res. Working Pap. 142:28.

25. Deng, X., Zhou, G., Li, H., Chen, J., and Civerolo, E. L. 2007. Detection of 'Candidatus Liberibacter asiaticus' from wampee (Clausena lansium Skeels) by nested PCR. Plant Health Progress. Online publication. doi:10.1094/PHP-2007-0419-01-BR

26. Doddapaneni, H., Liao, H., Lin, H., Bai, X., Zhao, X., Civerolo, E. L., Irey, M., Coletta-Filho, H., and Pietersen. G. 2008. Comparative phylogenomics and multi-gene cluster analyses of the Citrus Huanglongbing (HLB)-associated bacterium 'Candidatus Liberibacter'. BMC Res. Notes 1:72. Online publication. doi:10.1186/1756-0500-1-72

27. Duan, Y., Zhou, L., Hall, D. G., Li, W., Doddapaneni, H., H. Lin, Liu, L., Vahling, C. M., Gabriel, D. W., Williams, K. P., Dickerman, A., Sun, Y., and Gottwald, T. 2009. Complete genome sequence of citrus Huanglongbing bacterium, 'Candidatus Liberibacter asiaticus' obtained through metagenomics. Mol. Plant-Microbe Interact. 22:1011-1020.

28. Eichhorn, H., Lessing, F., Winterberg, B., Schirawski, J., Kamper, J., Muller, P., and Kahmann, R. 2006. A Ferroxidation/Permeation Iron Uptake System Is Required for Virulence in Ustilago maydis. Plant Cell 18:3332-3345

29. Eyer, J. R., and Crawford, R. F. 1933. Observations on the feeding habits of the potato psyllid (Paratrioza cockerelli Sulc) and the pathological history of the "psyllid yellows" which it produces. J. Econ. Entomol. 26846-850.

30. Gabbianelli, R., Scotti, R., Ammendola, S., Petrarca, P., Nicolini, L., and Andrea, B. 2011. Role of ZnuABC and ZinT in Escherichia coli O157:H7 zinc acquisition and interaction with epithelial cells. BMC Microbiol. 11:36. Online publication. doi:10.1186/1471-2180-11-36

31. Gao, F., Jifon, J., Yang, X., and Liu, T.-X. 2009. Zebra ship disease incidence on potato is influenced by timing of potato psyllid infestation, but not by the host plants on which they were reared. Insect Sci. 16:399408.

32. Gharalari, A. H., Nansen, C., Lawson, D. S., Gilley, J., Munyaneza, J. E., and Vaughn, K. 2009. Knockdown mortality, repellency, and residual effects of insecticides for control of adult Bactericera cockerelli (Hemiptera: Psyllidae). J. Econ. Entomol. 102:1032-1038.

33. Gil, R., Sabater-Muñoz, B., Latorre, A., Silva, F. J., and Moya, A. 2002. Extreme genome reduction in Buchnera spp.: toward the minimal genome needed for symbiotic life. Proc. Natl. Acad. Sci. USA 99:4454-4458.

34. Glynn, J. M., Islam, M. S., Bai, Y., Wen, A., Gudmestad, N. C., Civerolo, E. L., and Lin, H. 2012. Multilocus sequence typing of 'Candidatus Liberibacter solanacearum' isolates from North America and New Zealand. J. Plant Pathol. 94:223-238

35. González, V., Santamaría, R. I., Bustos, P., Hernández-González, I., Medrano-Soto, A., Moreno-Hagelsieb, G., Janga, S. C., Ramírez, M. A., Jiménez-Jacinto, V., Collado-Vides, J., and Dávila, G. 2006. The partitioned Rhizobium etli genome: genetic and metabolic redundancy in seven interacting replicons. Proc. Natl. Acad. Sci. USA 103:3834-3839.

36. Goolsby, J. A., Adamczyk, J. J., Bextine, B. E., Munyaneza, J. E., and Bester, G. 2007. Development of an IPM program for management of the potato psyllid to reduce incidence of zebra chip disorder in potatoes. Subtrop. Plant Sci. J. 59:85-94.

37. Gudmestad, N. C., and Secor, G. A. 2007. Zebra chip: a new disease of potato. Nebraska Potato Eyes 19:1-4.
38. Guedot, C., Horton, D. R., and Landolt, P. J. 2010. Sex attraction in Bactericera cockerelli (Hemiptera:Triozidae). Chem. Ecol. 39:1302-1308.

39. Hansen, A. K., Trumble, J. T., Stouthamer, R., and Paine, T. D. 2008. A new Huanglongbing (HLB) species, 'Candidatus Liberibacter psyllaurous', found to infect tomato and potato, is vectored by the psyllid Bactericeca cockerelli (Sulc). Appl. Environ. Microbiol. 74:5862-5865.

40. Hatch, T. P., Al-Hossainy, E., and Silverman, J. A. 1982. Adenine nucleotide and lysine transport in Chlamydia psittaci. J. Bacteriol. 150:662-670.

41. Henne, D. C., Workneh, F., and Rush, C. M. 2012. Spatial patterns and spread of potato zebra chip disease in the Texas Panhandle. Plant Dis. 96:948-956

42. Henne, D. C., Workneh, F., Wen, A., Price, J. A., Pasche, J. S., Gudmestad, N. C., and Rush, C. M. 2010. Characterization and epidemiological significance of plants grown from seed tubers affected by zebra chip disease. Plant Dis. 94:659-665.

43. Hung, T. H., Hung, S. C., Chen, C. N., Hsu, M. H., and Su, H. J. 2004. Detection by PCR of 'Candidatus Liberibacter asiaticus', the bacterium causing citrus huanglongbing in vector psyllids: Application to the study of vector-pathogen relationships. Plant Pathol. 53:96-102.

44. Ibarz Pavón, A. B., and Maiden, M. C. J. 2009. Multilocus sequence typing. Pages 129-140 in: Epidemiology of Microorganisms: Methods and Protocols. D. A. Caugant, ed. Humana Press, New York.

45. Jackson, B. C., Goolsby, J., Wyzykowski, A., Vitovsky, N., and Bextine, B. 2009. Analysis of genetic relationships between potato psyllid (Bactericera cockerelli) populations in the United States, Mexico and Guatemala using ITS2 and inter simple sequence repeat (ISSR) data. Subtrop. Plant Sci. 61:1-5.

46. Jagoueix, S., Bové, J. M., and Garnier, M. 1994. The phloem-limited bacterium of greening disease of citrus is a member of the alpha subdivision of the Proteobacteria. Int. J. Syst. Bacteriol. 44:379-386.

47. Jagoueix, S., Bové, J. M., and Garnier, M. 1996. PCR Detection of the two 'Candidatus Liberibacter' species associated with greening disease of citrus. Mol. Cell. Probes 10:43-50.

48. Lacey, L. A., Liu, T.-X., Buchman, J. L., Munyaneza, J. E., Goolsby, J. A., and Horton, D. R. 2011. Entomopathogenic fungi (Hypocreales) for control of potato psyllid, Bactericera cockerelli (Šlc.) (Hemiptera: Triozidae) in an area endemic for zebra chip disease of potato. Biol. Control 56:271-278

49. Levy, J., Raviddran, A., Gross, D., Tamborindeguy, and Pierson, E. 2011. Translocation of 'Candidatus Liberibacter solanacearum', the zebra chip pathogen, in potato and tomato. Phytopathology 101:1285-1291.

50. Li, W, Abad, J. A., French-Monar, R. D., Rascoe, J., Wen, A., Gudmestad, N. C., Secor, G. A., Lee, I. M., and Levy, L. 2009. Multiplex real-time PCR for detection, identification and quantification of 'Candidatus Liberibacter solanacearum' in potato plants with zebra chip. J. Microbiol. Methods 78:59-65.

51. Li, W., Hartung, J. S., and Levy, L. 2006. Quantitative real-time PCR for detection and identification of 'Candidatus Liberibacter' species associated with citrus huanglongbing. J. Microbiol. Methods 66:104-115.

52. Liefting, L. W., Perez-Egusquiza, Z. C., Clover, G. R. G., and Anderson, J. A. D. 2008. A new 'Candidatus Liberibacter' species in Solanum tuberosum in New Zealand. Plant Dis. 92:1474.

53. Liefting, L. W., Sutherland, P. W., Ward, L. I., Paice, K. L., Weir, B. S., and Clover, G. R. G. 2009. A new 'Candidatus Liberibacter' species associated with diseases of solanaceous crops. Plant Dis. 93:208-214.

54. Liefting, L. W., Ward, L. I., Shiller, J. B., and Clover, G. R. G. 2008. A New 'Candidatus Liberibacter' species in Solanum betaceum (Tamarillo) and Physallis peruviana (Cape gooseberry) in New Zealand. Plant Dis. 92:1588.

55. Liefting, L. W., Weir, B. S., Pennycook, S. R., and Clover, G. R. G. 2009. 'Candidatus Liberibacter solanacearum', a Liberibacter associated with plants in the family Solanaceae. Int. J. Syst. Evol. Microbiol. 59:22742276.

56. Lin, H., Doddapaneni, H., Munyaneza, J. E., Civerolo, E. L., Sengoda, V. G., Buchman, J. L., and Stenger, D. C. 2009. Molecular characterization and phylogenetic analysis of 16S rRNA from a new 'Candidatus Liberibacter' strain associated with zebra chip disease of potato (Solanum tuberosum L.) and the potato psyllid (Bactericera cockerelli Šulc). J. Plant Pathol. 91:215-219.

57. Lin, H., Islam, M. S., Bai, Y., Wen, A., Lan, S., Gudmestad, N. C., and Civerolo, E. L. 2012. Genetic diversity of 'Candidatus Liberibacter solanacearum' strains in the United States and Mexico revealed by simple sequence repeat markers. Eur. J. Plant Pathol. 132:297-308.

58. Lin, H., Lou, B., Glynn, J. M., Doddapaneni, H., Civerolo, E. L., Chen, C., Duan, Y., Zhou, L., and Vahling, C. M. 2011. The complete genome sequence of 'Candidatus Liberibacter solanacearum', the bacterium associated with potato zebra chip disease. PLoS ONE 6:e19135.

59. Lindgren, P. B., Peet, R. C., and Panopoulos, N. J. 1986. Gene cluster of 
Pseudomonas syringae pv. phaseolicola controls pathogenicity of bean plants and hypersensitivity on nonhost plants. J. Bacteriol. 168:512-522.

60. List, G. M. 1939. The effect of temperature upon egg deposition, egg hatch, and nymphal development of Paratrioza cockerelli (Šulc.). J. Econ. Entomol. 32:30-36.

61. Liu, D., Trumble, J. T., and Stouthamer, R. 2006. Genetic differentiation between eastern populations and recent introductions of potato psyllid (Bactericera cockerelli) into western North America. Entomol. Exp. Appl. 118:177-183.

62. Liu, D. G, and Trumble, J. T. 2004. Tomato psyllid behavioral responses to tomato plant lines and interactions of plant lines with insecticides. J. Econ. Entomol. 97:1078-1085.

63. Liu, D. G., and Trumble, J. T. 2005. Interactions of plant resistance and insecticides on the development and survival of Bactericera cockerelli [Šulc] (Homoptera: Psyllidae). Crop Prot. 24:111-117.

64. Liu, D. G., and Trumble, J. T. 2007. Comparative fitness of invasive and native populations of the potato psyllid (Bactericera cockerelli). Entomol. Exp. Appl. 123:35-42.

65. McDonald, B. A., and Linde, C. C. 2002. Pathogen population genetics, evolutionary potential, and durable resistance. Annu. Rev. Phytopathol. 40:349-379.

66. Miles, G. P., Samuel, M. A., Chen, J., Civerolo, E. L., and Munyaneza, J. E. 2010. Evidence of cell death is associated with zebra chip disease in potato tubers. Am. J. Potato Res. 87:337-349.

67. Moran, N. A., McCutcheon, J. P., and Nakabachi, A. 2008. Genomics and evolution of heritable bacterial symbionts. Annu. Rev. Genet. 42:165-190.

68. Morana, N. A., and Wernegreen, J. J. 2000. Lifestyle evolution in symbiotic bacteria: Insights from genomics. Trends Ecol. Evol. 15:321-326.

69. Munyaneza, J. E., Buchman, J. L., Upton, J. E., Goolsby, J. A., Crosslin, J. M., Bester, G., Miles, G. P., and Sengoda, V. G. 2008. Impact of different potato psyllid populations on zebra chip disease incidence, severity, and potato yield. Subtrop. Plant Sci. J. 60:27-37.

70. Munyaneza, J. E., Crosslin, J. M., and Buckman, J. L. 2009. Seasonal occurrence and abundance of the potato psyllid, Bactericera cockerelli, in South Central Washington. Am. J. Potato Res. 86:513-518.

71. Munyaneza, J. E., Crosslin, J. M., and Upton, J. E. 2007. Association of Bactericera cockerelli (Homoptera: Psyllidae) with "Zebra chip", a new potato disease in Southwestern United States and Mexico. J. Econ. Entomol. 100:656-663.

72. Munyaneza, J. E., Fisher, T. W., Sengoda, V. G., and Garczynski, S. F. 2010. First report of 'Candidatus Liberibacter solanacearum' associated with psyllid-affected carrots in Europe. Plant Dis. 94:639.

73. Munyaneza, J. E., Fisher, T. W., Sengoda, V. G., and Garczynski, S. F., Nissinen, A., Lemmetty, A. 2010. Association of "Candidatus Liberibacter solanacearum" with the psyllid, Trioza apicalis (Hemiptera: Triozidae) in Europe. J. Econ. Entomol. 4:1060-1070.

74. Munyaneza, J. E., Goolsby, J. A., Crosslin, J. M., and Upton, J. E. 2007. Further evidence that zebra chip potato disease in the Lower Rio Grande Valley of Texas is associated with Bactericera cockerelli. Subtrop. Plant Sci. J. 59:30-37.

75. Munyaneza, J. E., Sengoda, V. G., Buchman, J. L., and Fisher, T. W. 2012. Effects of temperature on 'Candidatus Liberibacter solanacearum' and zebra chip potato disease symptom development. Plant Dis. 96:18-23.

76. Munyaneza, J. E., Sengoda, V. G., Crosslin, J. M., De la Rosa-Lozano, G., and Sanchez, A. 2009. First report of 'Candidatus Liberibacter psyllaurous' in potato tubers with zebra chip disease in Mexico. Plant Dis. 93:552.

77. Munyaneza, J. E., Sengoda, V. G., Crosslin, J. M., Garzon-Tiznado, J. A., and Cardenas-Valenzuela, O. G. 2009. First report of 'Candidatus Liberibacter solanacearum' in tomato plants in México. Plant Dis. 93:1076.

78. Munyaneza, J. E., Sengoda, V. G., Stegmark, R., Arvidsson, A. K., Anderbrant, O., Yuvaraj, J. K., Ramert, B., and Nissinen, A. 2012. First report of 'Candidatus Liberibacter solanacearum' associated with psyllidaffected carrots in Sweden. Plant Dis. 96:453.

79. Munyaneza, J. E., Sengoda, V. G., Sundheim, L., and Meadow, R. 2012. First report of 'Candidatus Liberibacter solanacearum' associated with psyllid-affected carrots in Norway. Plant Dis. 96:454.

80. Nachappa, P., Shapiro, A. A., and Tamborindeguy, C. 2012. Effect of 'Candidatus Liberibacter solanacearum' on fitness of its insect vector Bactericera cockerelli (Hemiptera: Triozidae), on tomato. Phytopathology 102:41-46.

81. Navarre, D. A., Shakya, R., Holden, J., and Crosslin, J. M. 2009. LC-MS analysis of phenolic compounds in tubers showing zebra chip symptoms. Am. J. Pot. Res. 86:88-95.

82. Nelson, W. R., Fisher, T. W., and Munyaneza, J. E. 2011. Haplotypes of 'Candidatus Liberibacter solanacearum' suggest long-standing separation. Eur. J. Plant Pathol. 130:5-12.

83. Ochman, H. 2005. Genomes on the shrink. Proc. Natl. Acad. Sci. USA 102:11959-11960.
84. Paulsen, I. T., Kang, K. H., Hance, M. E., and Ren, Q. 2004. Genome analysis of membrane transport. Pages 113-126 in: Microbial Genomes. C. M. Fraser, T. D. Read, and K. E. Nelson, eds. Humana Press Inc., Totowa, NJ.

85. Peng, L., Trumble, J. T., Munyaneza, J. E., and Liu, T. X. 2011. Repellency of kaolin particle film to potato psyllid, Bactericera cockerelli (Hemiptera:psyllidae), on tomato under laboratory and field conditions. Pest Manage. Sci. 67:815-824.

86. Pitman, A. R., Drayton, G. M., Kraberger, S. J., Genet, R. A., and Scott, I. A. W. 2011. Tuber transmission of 'Candidatus Liberibacter solanacearum' and its association with zebra chip on potato in New Zealand. Eur. J. Plant Pathol. 129:389-398.

87. Primrose, S. B., and Twyman, R. M. 2003. Principles of Genome Analysis and Genomics, third ed. S. B. Primrose and R. M. Twyman, eds. Blackwell Publishing Company, Malden, MA.

88. Raddadi, N., Gonella, E., Camerota, C., Pizzinat, A., Tedeschi, R., Crotti, E., Mandrioli, M., Bianco, P. A., Daffonchio, D., and Alma, A. 2011. 'Candidatus Liberibacter europaeus' sp. nov. that is associated with and transmitted by the psyllid Cacopsylla pyri apparently behaves as an endophyte rather than a pathogen. Environ. Microbiol. 13:414426.

89. Ramanan, N., and Wang, Y. 2000. A high-affinity iron permease essential for Candida albicans virulence. Science 288:1062-1064.

90. Rashed, A., Nash, T. D., Paetzold, L., Workneh, F., and Rush, C. M. 2012. Transmission efficiency of 'Candidatus Liberibacter solanacearum' and potato zebra chip disease progress in relation to pathogen titer, vector numbers, and feeding sites. Phytopathology 102:1079-1085.

91. Ravindran, A., Levy, J., Pierson, E., and Gross, D. C. 2011. Development of primers for improved PCR detection of the potato zebra chip pathogen, 'Candidatus Liberibacter solanacearum'. Plant Dis. 95:1542-1546.

92. Ravindran, A., Levy, J., Pierson, E., and Gross, D. C. 2012. Development of a loop-mediated isothermal amplification procedure as a sensitive and rapid method for the detection of 'Candidatus Liberibacter solanacearum' in potatoes and psyllids. Phytopathology 102:899-907.

93. Rodriguez La Torre, J. J. 2012. Movement and accumulation of 'Candidatus Liberibacter solanacearum' in potato plant. Ph.D. dissertation, North Dakota State University, Fargo, ND.

94. Romney, V. E. 1939. Breeding areas of the tomato psyllid, Paratrioza cockerelli (Šlc.). J. Econ. Entomol. 32:150-151.

95. Rush, C. M., Henne, D. C., Workneh, F., and Paetzold, L. 2010. Investigating titer variation of 'Candidatus Liberibacter solanacearum' in individual potato psyllids. In: Proc. 10th Annu. Zebra Chip Rep. Session. F. Workneh and C. M. Rush, eds. Dallas.

96. Saurabh, B., Sneha, S., Suvidya, R., Pramod, K., and B. Shailesh. 2011. Analysis of distribution and significance of simple sequence repeats in enteric bacteria Shigella dysenteriae SD197. Bioinformation 6:348-351.

97. Schmitz-Esser, S., Haferkamp, I., Knab, S., Penz, T., Ast, M., Kohl, C., Wagner, M., and Horn, M. 2008. Lawsonia intracellularis contains a gene encoding a functional rickettsia-like ATP/ADP translocase for host exploitation. J. Bacteriol. 190:5746-5752.

98. Secor, G. A., and Rivera-Varas, V. V. 2004. Emerging diseases of cultivated potato and their impact on Latin America. Rev. Latinoam. Papa (Suppl.) 1:1-8.

99. Secor, G. A., Rivera, V. V., Abad, J. A., Lee, I. M., Clover, G. R. G., Liefting, L. W., Li, X., and De Boer, S. H. 2009. Association of 'Candidatus Liberibacter solanacearum' with the zebra chip disease of potato established by graft and psyllid transmission, electron microscopy, and PCR. Plant Dis. 93:574-583.

100. Semetey, O, Gatineau, F, Bressan, A, and Boudon-Padieu, E. 2007. Characterization of a $\gamma-3$ proteobacteria responsible for the syndrome basses-richesses of sugar beet transmitted by Penastiridius sp. (Hemiptera, Cixiidae). Phytopathology 97:72-78

101. Sengoda, V. G., Munyaneza, J. E., Crosslin, J. M., Buchman, J. L., and Pappu, H. R. 2010. Phenotypic and etiological differences between psyllid yellows and zebra chip diseases of potato. Am. J. Potato Res. 87:41-49.

102. Simpson, A. J., Reinach, F. C., Arruda, P., Abreu, F. A., Acencio, M., Alvarenga, R. Alves, L. M., Araya, J. E., Baia, G. S., Baptista, C. S., Barros, M. H., Bonaccorsi, E. D., Bordin, S., Bové, J. M., Briones, M. R., Bueno, M. R., Camargo, A. A., Camargo, L. E., Carraro, D. M., Carrer, H., Colauto, N. B., Colombo, C., Costa, F. F., Costa, M. C., Costa-Neto, C. M., Coutinho, L. L., Cristofani, M., Dias-Neto, E., Docena, C., El-Dorry, H., Facincani, A. P., Ferreira, A. J., Ferreira, V. C., Ferro, J. A., Fraga, J. S., Franca, S. C., Franco, M. C., Frohme, M., Furlan, L. R., Garnier, M., Goldman, G. H., Goldman, M. H., Gomes, S. L., Gruber, A., Ho, P. L., Hoheisel, J. D., Junqueira, M. L., Kemper, E. L., Kitajima, J. P., Krieger, J. E., Kuramae, E. E., Laigret, F., Lambais, M. R., Leite, L. C., Lemos, E. G., Lemos, M. V., Lopes, S. A., Lopes, C. 
R., Machado, J. A., Machado, M. A., Madeira, A. M., Madeira, H. M., Marino, C. L., Marques, M. V., Martins, E. A., Martins, E. M., Matsukuma, A. Y., Menck, C. F., Miracca, E. C., Miyaki, C. Y., Monteriro-Vitorello, C. B., Moon, D. H., Nagai, M. A., Nascimento, A. L., Netto, L. E., Nhani, A., Nobrega, F. G., Jr., Nunes, L. R., Oliveira, M. A., de Oliveira, M. C., de Oliveira, R. C., Palmieri, D. A., Paris, A., Peixoto, B. R., Pereira, G. A., Pereira, H. A., Pesquero, J. B., Jr., Quaggio, R. B., Roberto, P. G., Rodrigues, V., de M Rosa, A. J., de Rosa, V. E., de Sá, R. G., Santelli, R. V., Sawasaki, H. E., da Silva, A. C., da Silva, A. M., da Silva, F. R., da Silva, W. A., da Silveira, J. F., Jr., Silvestri, M. L., Siqueira, W. J., de Souza, A. A., de Souza, A. P., Terenzi, M. F., Truffi, D., Tsai, S. M., Tsuhako, M. H., Vallada, H., Van Sluys, M. A., Verjovski-Almeida, S., Vettore, A. L., Zago, M. A., Zatz, M., Meidanis, J., and Setubal, J. C. 2000. The genome sequence of the plant pathogen Xylella fastidiosa. The Xylella fastidiosa consortium of the organization for nucleotide sequencing and analysis. Nature 406:151-159.

103. Swisher, K. D., Munyaneza, J. E., and Crosslin, J. M. 2012. High resolution melting analysis of the cytochrome oxidase I gene identifies three haplotypes of the potato psyllid in the United States. Environ. Entomol. 41:1019-1028.

104. Teixeira, D. C., Saillard, C., Couture, C., Martins, E. C., Wulff, N. A., Eveillard-Jagoueix, S., Yamamoto, P. T., Ayres, A. J., and Bové, J. M. 2008. Distribution and quantification of 'Candidatus Liberibacter americanus', agent of huanglongbing disease of citrus in São Paulo State, Brazil, in leaves of an infected sweet orange tree as determined by PCR. Mol. Cell. Probes 22:139-150.

105. Vahling, C. M., Duan, Y., and Lin, H. 2010. Characterization of an ATP translocase identified in the destructive plant pathogen 'Candidatus Liberibacter asiaticus'. J. Bacteriol. 192:834-840.

106. Vahling-Armstrong, C. M., Zhou, H., Benyon, L., Morgan, J. K., and Duan, Y. 2012. Two Plant Bacteria, S. meliloti and ' $\mathrm{Ca}$. Liberibacter asiaticus', Share Functional znuABC homologues that encode for a high affinity zinc uptake system. PLoS ONE 7:e37340.

107. Van Sluys, M. A., de Oliveira, M. C., Monteiro-Vitorello, C. B., Miyaki, C. Y., Furlan, L. R., Camargo, L. E. A., da Silva, A. C. R., Moon, D. H., Takita, M. A, Lemos, E. G., Machado, M. A., Ferro, M. I., da Silva, F. R., Goldman, M.H., Goldman, G.H., Lemos, M.V., El-Dorry, H., Tsai, S. M., Carrer, H., Carraro, D. M., de Oliveira, R. C., Nunes, L. R., Siqueira, W. J., Coutinho, L. L., Kimura, E. T., Ferro, E. S., Harakava, R., Kuramae, E. E., Marino, C. L., Giglioti, E., Abreu, I. L., Alves, L. M., do Amaral, A. M., Baia, G. S., Blanco, S. R., Brito, M. S., Cannavan, F. S., Celestino, A. V., da Cunha, A. F., Fenille, R. C., Ferro, J. A., Formighieri, E. F., Kishi, L. T., Leoni, S. G., Oliveira, A. R., Rosa,
V. E., Sassaki, F. T., Jr., Sena, J. A., de Souza, A. A., Truffi, D., Tsukumo, F., Yanai, G. M., Zaros, L. G., Civerolo, E. L., Simpson, A. J., Almeida, N. F., Setubal, J. C., Jr., and Kitajima, J. P. 2003. Comparative analyses of the complete genome sequences of Pierce's disease and citrus variegated chlorosis strains of Xylella fastidiosa. J Bacteriol. 185:1018-1026.

108. Wallis, C. M., Chen, J., and Civerolo, E. L. 2012. Zebra chip-diseased potato tubers are characterized by increased levels of host phenolics, amino acids, and defense-related proteins. Physiol. Mol. Plant Pathol. 78:66-72.

109. Wallis, R. L. 1955. Ecological studies on the potato psyllid as a pest of potatoes. U.S. Dep. Agric. Tech. Bull. 1107:1-24.

110. Wen, A., Mallik, I., Alvarado, V. Y., Pasche, J. S., Wang, X., Li, W., Levy, L., Lin, H., Scholthof, H., Mirkov, E., Rush, C. M., and Gudmestad, N. C. 2009. Detection, distribution, and genetic variability of 'Candidatus Liberibacter' species associated with the zebra complex disease of potato in the North America. Plant Dis. 93:1102-115.

111. Wood, D. W., Setubal, J. C., Kaul, R., Monks, D. E., Kitajima, J. P., Okura. V. K., Zhou, Y., Chen, L., Wood, G. E., Almeida, N. F., Woo, L., Jr., Chen, Y., Paulsen, I. T., Eisen, J. A., Karp, P. D., Bovee, D., Sr., Chapman, P., Clendenning, J., Deatherage, G., Gillet, W., Grant, C., Kutyavin, T., Levy, R., Li, M. J., McClelland, E., Palmieri, A., Raymond, C., Rouse, G., Saenphimmachak, C., Wu, Z., Romero, P., Gordon, D., Zhang, S., Yoo, H., Tao, Y., Biddle, P., Jung, M., Krespan, W., Perry, M., Gordon-Kamm, B., Liao, L., Kim, S., Hendrick, C., Zhao, Z. Y., Dolan, M., Chumley, F., Tingey, S. V., Tomb, J. F., Gordon, M. P., Olson, M. V., and Nester, E. W. 2001. The Genome of the natural genetic engineer Agrobacterium tumefaciens C58. Science 294:23172323.

112. Workneh, F., Henne, D. C., Childers, A. C., Paetzold, L., and Rush, C. M. 2012. Assessments of the edge effect in intensity of potato zebra chip disease. Plant Dis. 96:943-947.

113. Yalpani, N., Silverman, P., Wilson, T. M., Kleier, D. A., and Raskin, I. 1991. Salicylic acid is a systemic signal and an inducer of pathogenesisrelated proteins in virus-infected tobacco. Plant Cell 3:809-818.

114. Yang, X.-B., Zhang, Y.-M., Hua, L., Peng, L.-N., Munyaneza, J. E., Trumble, J. T., and Liu, T.-X. 2010. Repellency of selected biorational insecticides to potato psyllid, Bactericera cockerelli (Hemiptera: Psyllidae). Crop Prot. 29:1320-1324.

115. Zhang, S., Flores-Cruz, Z., Zhou, L., Kang, B. H., Fleites, L. A., Gooch, M. D., Wulff, N. A., Davis, M. J., Duan, Y. P., and Gabriel, D. W. 2011. ' $\mathrm{Ca}$. Liberibacter asiaticus' carries an excision plasmid prophage and a chromosomally integrated prophage that becomes lytic in plant infections. Mol. Plant-Microbe Interact. 24:458-468. 